Article

\title{
The Effects of Land Use and Land Cover Geoinformation Raster Generalization in the Analysis of LUCC in Portugal
}

\author{
Bruno M. Meneses ${ }^{1, * \mathbb{D}}$, Eusébio Reis ${ }^{1}$, Rui Reis ${ }^{2}$ and Maria J. Vale ${ }^{2}$ \\ 1 Centre for Geographical Studies, Institute of Geography and Spatial Planning, Universidade de Lisboa. \\ Edif. IGOT, Rua Branca Edmée Marques, 1600-276 Lisbon, Portugal; eusebioreis@campus.ul.pt \\ 2 General Directorate for Territorial Development (DGT), Rua da Artilharia Um, 107, \\ 1099-052 Lisbon, Portugal; rui.reis@dgterritorio.pt (R.R.); mvale@dgterritorio.pt (M.J.V.) \\ * Correspondence: bmeneses@campus.ul.pt; Tel.: +351-213-819-600
}

Received: 6 July 2018; Accepted: 22 September 2018; Published: 26 September 2018

\begin{abstract}
Multiple land use and land cover (LUC) datasets are available for the analysis of LUC changes (LUCC) in distinct territories. Sometimes, different LUCC results are produced to characterize these changes for the same territory and the same period. These differences reflect: (1) The different properties of LUC geoinformation (GI) used in the LUCC assessment, and (2) different criteria used for vector-to-raster conversion, namely, those deriving from outputs with different spatial resolutions. In this research, we analyze LUCC in mainland Portugal using two LUC datasets with different properties: Corine Land Cover (CLC 2006 and 2012) and LUC official maps of Portugal (Carta de Ocupação do Solo, COS 2007 and 2010) provided by the European Environment Agency (EEA) and the General Directorate for Territorial Development (DGT). Each LUC dataset has undergone vector-to-raster conversion, with different resolutions (10, 25, 50, 100, and $200 \mathrm{~m})$. LUCC were analyzed based on the vector GI of each LUC dataset, and with LUC raster outputs using different resolutions. Initially, it was observed that the areas with different LUC types in two LUC datasets in vector format were not similar-a fact explained by the different properties of this type of GI. When using raster GI to perform the analysis of LUCC, it was observed that at high resolutions, the results are identical to the results obtained when using vector GI, but this ratio decreases with increased cell size. In the analysis of LUCC results obtained with raster LUC GI, the outputs with pixel size greater than $100 \mathrm{~m}$ do not follow the same trend of LUCC obtained with high raster resolutions or using LUCC obtained with vector GI. These results point out the importance of the factor form and the area of the polygons, and different effects of amalgamation and dilation in the vector-to-raster conversion process, more evident at low resolutions. These findings are important for future evaluations of LUCC that integrate raster GI and vector/raster conversions, because the different LUC GI resolution in line with accuracy can explain the different results obtained in the evaluation of LUCC. The present work demonstrates this fact, i.e., the effects of vector-to-raster conversions using various resolutions culminated in different results of LUCC.
\end{abstract}

Keywords: LUC; LUCC; geoinformation properties; raster generalization; spatial analysis

\section{LUC: Multiscale Framework, Geoinformation Availability, and Raster Generalization Process}

\subsection{LUC Changes: An Overview}

Global land use and land cover changes (LUCC) research emerged in recent decades when its influence on climate was recognized [1], especially from the mid-1970s, when modification surface albedo and thus surface-atmosphere energy exchanges were verified $[2,3]$. 
In the following years, the influence of other processes connected to LUCC were verified, for example, evapotranspiration variation and interference in the water cycle [4], impacts on biotic diversity [5-7], soil degradation [8-11], and other environmental problems. LUCC and land use intensification are major drivers of ecosystem degradation, biodiversity loss, ecosystem service depletion, and landscape change [7,12-15]. Remote sensing, and other data available, in the last decades allow us to obtain a consistent and global picture of the world's landscapes [1].

Land use and land cover (LUC) of Europe comprises a myriad of different landscapes and land uses that reflect topography, as well as climatic and historical changes [16]. In this territory, large LUCC are also verified [17], especially the transitions affecting cropland, forests, and other areas caused by urban growth, and many actions/rules have been implemented to reduce the impacts of LUCC [18].

In Portugal, there are different studies about LUCC [19-24], and these point out large LUCC in recent years, especially with loss of area in forest and agricultural classes and gain of area in urban classes. The LUC datasets used in these studies has different properties (scale, minimum mapping unit, spatial resolution, etc.) and is produced by different entities or individual users, for example, the official Portuguese Land Cover Map (Carta de Ocupação do Solo, COS) produced and made available by the General Directorate for Territorial Development (DGT) [25], the Corine Land Cover (CLC) produced by DGT and made available by the European Environment Agency (EEA) and DGT, the LUC classification by satellite images [26,27], and even vectorization on air-photo maps (visual interpretation) made available by different producers or users [28], among others.

Despite some differences in LUCC results from study to study, these can be explained, to a large extent, by the different properties of the geoinformation (GI) used in each study (e.g., References $[19,29,30])$. These differences can also be related to the processes performed with geographic information system (GIS) tools, in particular the vector-to-raster conversion. Within this vector-to-raster conversion, the properties assigned to data inputs, for instance the cell size or cell assignment method (which, in the polygon-to-raster conversion, is the method used to determine how the value will be assigned to the cell when more than one feature falls within a cell [31], center, maximum area, or maximum combined area, among others), can induce changes in the obtained results.

\subsection{LUC Geoinformation}

The volume of GI available has greatly increased in recent years. LUC information obtained automatically, semi-automatically, and manually is not an exception, especially because the acquisition is increasingly made in shorter periods (temporal coverage), especially for LUC geoinformation obtained by satellite imagery [32,33]. Furthermore, and more recently, there have been more diverse means of data acquisition, such as unmanned aerial vehicles (UAVs) [34,35]. In addition, there is an increase not only in the amount of available geoinformation, but also in the available data resolution [36-38].

As a result of the increased availability of LUC geoinformation, coming from different sources and collected for different purposes, certain issues have to be considered, and some spatial evaluations have to be made, because data properties vary greatly among the various available datasets. GI properties can be critical in evaluating the quality of the results, because LUC datasets with different properties can lead to different results, which in turn lead to different interpretations and conclusions regarding the LUCC for the same territory under analysis [39].

Several authors have focused also on the quality of GI [40-44], because this can be a decisive issue in obtaining results with high accuracy and quality [45], whether for LUCC or for another type of spatial assessment.

\subsection{LUC Geoinformation Generalization}

Most analyses of LUCC are produced with GI in raster format, because certain models and tools only support this structure, but questions may arise about the accuracy obtained after vector-to-raster conversion, because real boundaries of elements (lakes, buildings, etc.) are affected or changed in this 
process. These effects are the result of vector-to-raster conversion, specifically data amalgamation and dilation, emphasizing the importance of cell size [46-48]. In general, it is expected that low resolutions will have negative effects, due to the factors mentioned above.

Shea and McMaster [49] describe the generalization process in 12 processes: Simplification, smoothing, aggregation, amalgamation, merging, collapse, refinement, typification, exaggeration, enhancement, displacement, and classification.

With a GIS, it is possible to use different data models to manage geoinformation [50,51]. At the conceptual level, two models are possible [52]: Object-based ones, where the space is divided into discrete and identifiable entities, each with several properties in terms of geospatial position (e.g., rivers, roads, buildings, etc.); and field-based ones, integrating a continuous mathematical function that for each position of the space returns a value (e.g., temperature, evapotranspiration, insolation, etc.). At the logical level, two structures are available in GIS [52]: Vector (geoinformation represented in lines, points, and polygons), and raster (the space is represented as a regular tessellation of disjoint cells, sometimes called pixels, usually squares, each having an attribute value). The degree of abstraction involved when considering field and object models increases successively from reality to the conceptual model, the logical model, and finally the physical model $[51,53]$.

GIS allows users to produce new coverages by reducing the amount of detail in an existing coverage [45], for example, simplifying LUC polygon boundaries at different scales, but this "generalization" may or may not reduce the number of objects in the coverage $[28,54]$. The generalization process also occurs when combining polygons with similar characteristics, reducing the number of objects in the coverage.

In raster data, the generalization process usually reduces both the number of objects and the amount of detail [55]. Veregin and McMaster [56] reported that in vector data (e.g., environmental data), the spatial and thematic components can be generalized independently; on the other hand, in a raster generalization this is almost always accomplished by the thematic component alone and the thematic content of maps is changed, thus thematic accuracy and data quality in general can be affected. The confusion matrix [57] is the most common method for assessing the accuracy of thematic data, such as land cover, and is widely used for LUCC assessment (e.g., References [58-62]). The errors that occur in vector-to-raster conversions [63,64] can affect the results; for example, Bettinger et al. [63] observed in the conversion of polygons that forest patch metrics were affected.

In the spatial and temporal LUCC assessment of a given territory, it is important to understand, which impacts may result from the LUCC. Evaluation of LUCC has been done in different territories with different scales of analysis, goals, and methods, but also based on different LUC geoinformation datasets (e.g., References [65-68]). This is a starting point of this work: The vector-to-raster conversion of datasets with different scales is performed and the quality of the LUCC results is evaluated, pointing out the main concerns to have in mind when processing LUC data.

\section{Objectives}

The first goal of this work is to assess the effects resulting from the GI vector-to-raster conversion, using two LUC datasets with different properties (COS and CLC); the second goal is to evaluate the consistency of LUCC in mainland Portugal obtained by LUC GI referred to above at different resolutions.

As a first approach, the areas of each class in different LUC datasets with different resolutions are reviewed and compared with vector GI; then, using different raster resolutions outputs, the gain and loss of LUCC area are calculated (between raster outputs and also raster verses vector), and the differences between each LUC type (classes), are analyzed. This evaluation is crucial to understand whether the LUCC results vary significantly when LUC datasets with different resolutions are introduced in the model. 


\section{LUC of Portugal}

Mainland Portugal $\left(88,962.5 \mathrm{~km}^{2}\right)$ is composed of a highly diversified landscape. It integrates large forest areas in the central and northern regions and vast agricultural land in the southern regions (Figure 1), with emphasis on the Alentejo, where the Alqueva Dam (built in 2002) generates a wide water body (the largest artificial reservoir in Western Europe). Artificial surfaces stand out, especially near the coast, and are particularly relevant in the Lisbon and Oporto metropolitan areas.

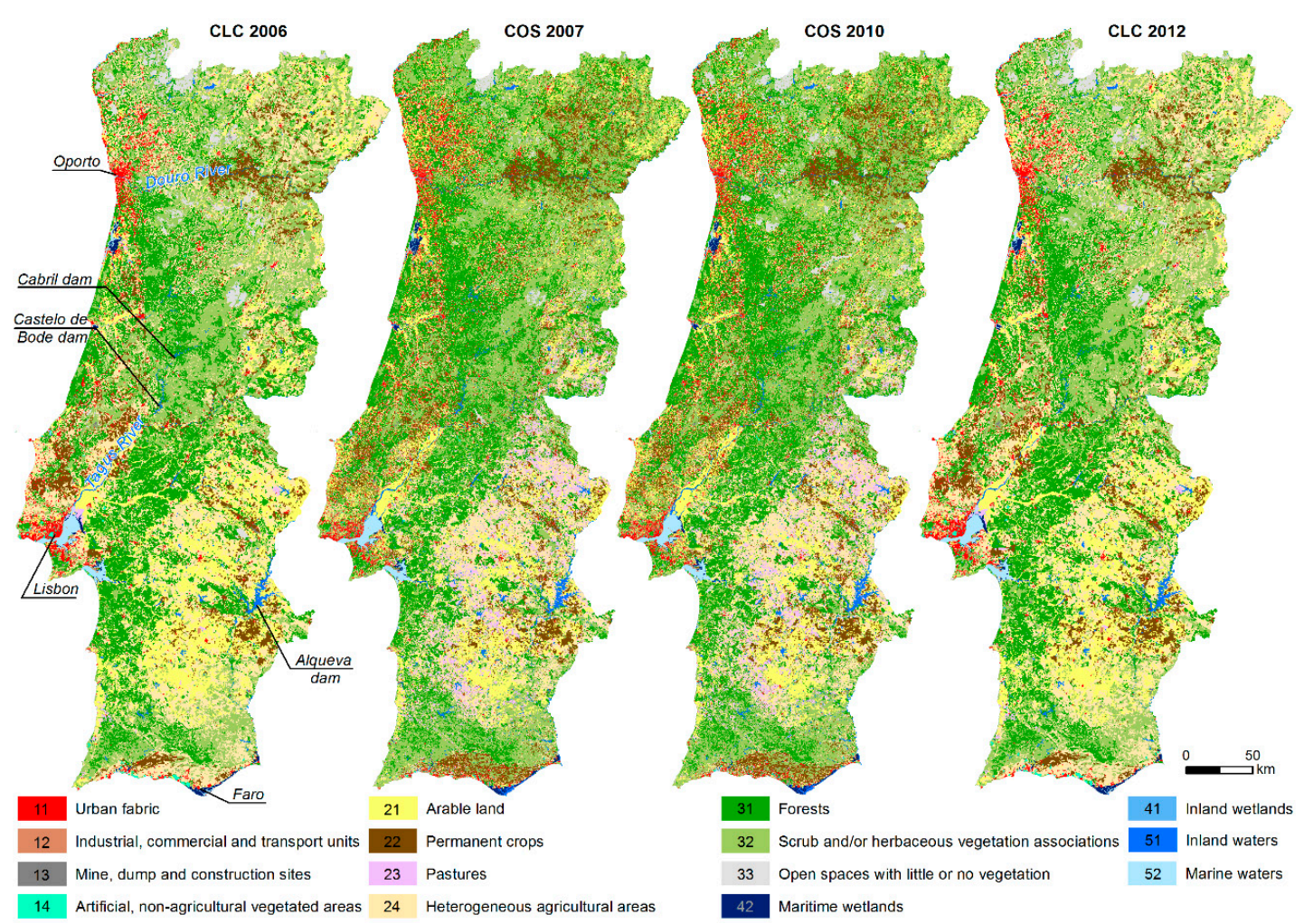

Figure 1. Land use and land cover of mainland Portugal in different years (Carta de Ocupação do Solo (COS) and Corine Land Cover (CLC) geoinformation, source: General Directorate for Territorial Development (DGT)).

The assessment of recent decades, this territory has shown significant LUCC, with a large reduction of forest area as a result of yearly forest fires, pinewood nematode infestation [69], and the transition to other types of LUC (e.g., conversion to agricultural land) [22].

Assessing the GI properties is essential to understand the different results on LUCC obtained by different research and to formulate solid conclusions. For example, Figure 1 shows the spatial difference between the soils occupied by a certain type of LUC (e.g., arable land, pastures, heterogeneous agricultural areas, forest) on CLC and COS for the considered years (more details can be found in the attribute tables analysis). Although the cartographic properties are different, the area of arable land in CLC 2006 was higher compared to COS 2007 (about 0.56\%), but on the other hand, the forest area was higher in COS 2007 compared to CLC 2006 (approximately 1.66\%). These results show the differences that can be obtained in the analysis of LUCC with different LUC GI. Despite the maps being from different years, the period between them is very small, so the results should be similar, with these differences highlighting the importance of understanding certain variations in studying LUCC, particularly those variations, due to the different properties of GI, since there may be different results for the same (or similar) periods, due to a certain set of factors (e.g., scale, spatial resolution, minimum mapping unit, etc.).

Comparing the total areas for LUC classes in different datasets, in general, these show similar variation trends (Figure 2), except class 33 (open spaces with little or no vegetation) with the most 
significant inverse variations. The line at $45^{\circ}$ in the graphs of Figure 2 will then be the reference line, above which the area of land class is decreasing, and below which it is increasing over the selected two years.
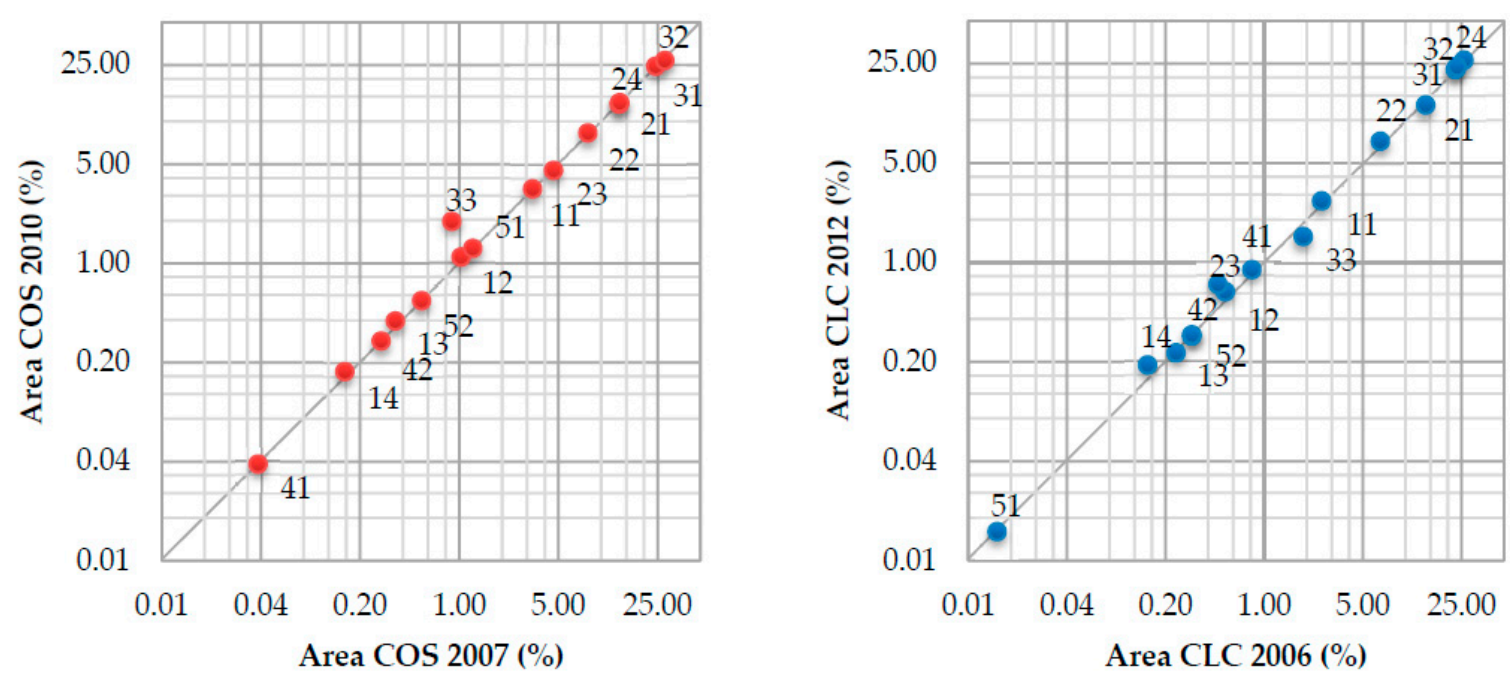

Figure 2. Land use and land cover (LUC, total area) of mainland Portugal in different years, obtained by COS and CLC (vector geoinformation). LUC codes: See legend in Figure 1.

\section{Data, Tools, and Methods}

\subsection{LUC Geoinformation and Multispecifications}

The LUC GI used in this research was the COS (2007 and 2010) and the CLC (2006 and 2012). These GI datasets have different properties [25,70], as shown in Table 1. The LUC nomenclature used in these datasets coincides at the first three levels (the same as CLC [71]), allowing the comparison between the two datasets. For this study, only the datasets with greater temporal proximity were selected. Due to the extent of the study area, the second level of the LUC nomenclature used in CLC (which is equal to the second level of the COS nomenclature) was selected for the analysis of LUCC.

Table 1. Characteristics and properties of LUC geoinformation.

\begin{tabular}{|c|c|c|}
\hline Characteristics & Land Cover Maps of Portugal & Corine Land Cover \\
\hline Acronym & $\cos$ & CLC \\
\hline Scale & $1: 25,000$ & $1: 100,000$ \\
\hline Minimum Mapping Unit (MMU) & 1 ha & 25 ha \\
\hline Data model & Vector & Vector \\
\hline Spatial representation & Polygons & Polygons \\
\hline Minimum distance between lines & $20 \mathrm{~m}$ & $100 \mathrm{~m}$ \\
\hline Base data & Air-photo maps & Satellite images \\
\hline Spatial resolution & $0.5 \mathrm{~m}$ & $20 \mathrm{~m}$ \\
\hline \multirow{2}{*}{ Nomenclature } & Hierarchical (5 levels) & Hierarchical (3 levels) \\
\hline & 225 classes & 44 classes \\
\hline Production method & Visual interpretation & $\begin{array}{l}\text { Semi-automated production and visual } \\
\text { interpretation }\end{array}$ \\
\hline Projected Coordinate System & ETRS 1989 Portugal TM06 & ETRS 1989 Portugal TM06 \\
\hline Projection & Transverse Mercator & Transverse Mercator \\
\hline Geographic Coordinate System & GCS ETRS 1989 & GCS ETRS 1989 \\
\hline Datum & ETRS 1989 & ETRS 1989 \\
\hline Data availability (years) & $1995 *, 2007,2010$ & 1990, 2000, 2006, 2012 \\
\hline
\end{tabular}

* Specific nomenclature (hierarchical: two levels with 19 classes maximum at second level) defined to support Kyoto reporting of emissions and carbon sequestration in Portugal [72]. 
The administrative boundaries used to perform the study are those of the Official Administrative Map of Portugal (CAOP 2016), in vector structure, provided by DGT. Two LUC datasets (vector GI) were cut and compatibilized by these limits and stored in a geodatabase. The new features resulting from this process have the same total area $\left(88,962.5 \mathrm{~km}^{2}\right)$ in both maps.

However, there are some differences in the statistics for the feature dataset areas (Table 2). COS features present polygons with a mean area of approximately 11.5 ha in the two years considered; on the contrary, the CLC shows inconsistency between the two years, since features of 2006 and 2012 have polygons with a mean area of 271.6 and $255.2 \mathrm{ha}$, respectively. The results also differ greatly when considering the number of polygons and the maximum area.

Table 2. Descriptive statistics of LUC GI datasets (vector) after the clip and compatibility by the Official Administrative Map of Portugal (CAOP) 2016 (LUC data obtained by COS and CLC).

\begin{tabular}{ccccc}
\hline & \multicolumn{2}{c}{ COS } & $\mathbf{2 0 0 6}$ & CLC \\
\cline { 2 - 5 } & $\mathbf{2 0 0 7}$ & $\mathbf{2 0 1 0}$ & 32,761 & 34,867 \\
\hline Total polygons & 777,262 & 777,289 & 0.01 & 0.01 \\
\hline Minimum area of polygons (ha) & 0.01 & 0.01 & $216,104.0$ & $156,114.0$ \\
\hline Maximum area of polygons (ha) & $22,439.9$ & $25,799.2$ & 271.6 & 255.2 \\
\hline Mean area of polygons (ha) & 11.5 & 11.5 & 2368.3 & 2136.3 \\
\hline Standard Deviation area (ha) & 93.5 & 90.9 & &
\end{tabular}

\subsection{Tools and LUCC Methodology}

The methods used are sequential, with the following steps (Figure 3): (1) introduce the dataset used in research; (2) the vector GI was converted to raster with different resolutions; (3) calculation of the absolute and relative LUCC and analyze the impact of pixel sizes on LUC area; (4) using the vector GI, calculation the compactness coefficient $\left(\mathrm{K}_{\mathrm{c}}\right)$ and ratio of polygons by total area $\left(\mathrm{PA}_{\mathrm{Rt}}\right)$ for each LUC class; (5) calculation of the correlation coefficients between the indices mentioned above $\left(\mathrm{K}_{\mathrm{c}}\right.$ average and $\mathrm{PA}_{\mathrm{Rt}}$ ) and the area variation between different raster outputs (with different resolution) verses vector GI; (6) using these indices and this variation area, the principal component analysis was used to performed LUC class groupings.

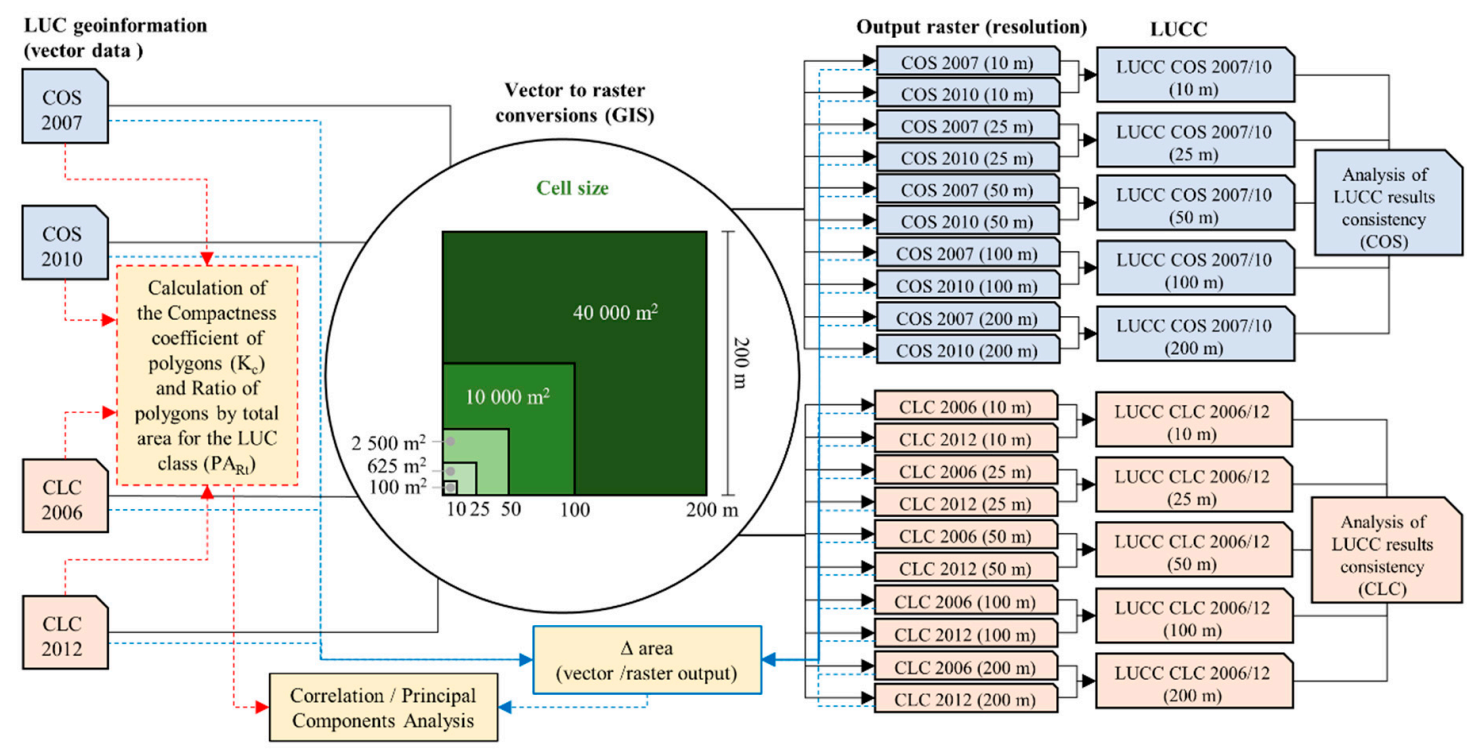

Figure 3. Methodological scheme: LUC GI conversion, LUC outputs, and LUCC.

ArcGIS 10.5 was the selected software to support all GIS processes performed in this research: Vector-to-raster GI conversions, LUCC analysis, and constructing the final LUC maps. In the conversion 
of LUC polygon features to raster datasets with the software, the cell assignment type selected was "cell center," where the polygon that overlaps the center of the cell yields the attribute to assign to the cell. With the "cell center" option, the priority is specified, and once the cell center falls within only one feature, the attribute of that feature is assigned to the cell [31].

LUCC areas were calculated by subtracting to the LUC final area $\left(t_{2}\right)$ the LUC initial area $\left(t_{1}\right)$ of each LUC dataset $\left(t_{2}-t_{1}\right)$ [73]. LUC transition tables [74,75] were also prepared for each LUC dataset, to understand in detail LUCC between various LUC types. For this assessment, the LUC GI vector structure (COS and CLC) was converted to raster (using GIS) with different resolutions $(10,25,50,100$, and $200 \mathrm{~m}$ ). These results enabled us to quantify the differences between LUCC at different resolution levels (Figure 3) and allowed the comparison of LUCC trends obtained with different LUC datasets.

LUCC results presented in this research were computed with the total area of each LUC vector or raster at different resolutions. Section 5.1 presents the comparison between the total area of mainland Portugal using LUC vector and LUC raster at different resolutions.

The compactness coefficient $\left(\mathrm{K}_{\mathrm{c}}\right)$ was calculated as a measure to characterize the polygonal form for all GI datasets. This coefficient, mainly used in the calculation of watershed forms [76], is essentially a relationship between the shape of the LUC polygons and that of a circle, and is determined by the following equation:

$$
\mathrm{K}_{\mathrm{c}}=\frac{0.28 * P}{\sqrt{A}},
$$

where $P$ is the length of the perimeter and $A$ is the area of the polygon.

The ratio of polygons by total area for the LUC class $\left(\mathrm{PA}_{\mathrm{Rt}}\right)$ was also obtained. This ratio provides the variation of polygons by each LUC class and is obtained by the following equation:

$$
\mathrm{PA}_{\mathrm{Rt}}=\frac{\sum_{k=1}^{n} k}{\sum_{A=1}^{n} A}
$$

where $K$ is the number of polygons by LUC class and $A$ is the area of the polygons.

These two variables and absolute and relative LUCC were integrated into the statistical analysis performed in Statistica 7 software. All variables were standardized in Statistica 7.

\section{Results and Discussion}

\subsection{Area of Mainland Portugal at Different Raster Resolutions}

Comparing the LUC outputs at different raster resolutions for the total area of mainland Portugal (GI with same coordinate system), it was observed that the total area shows slight variations depending on the selected raster resolution for each LUC dataset (Table 3). Furthermore, the loss or gain of area between the different resolutions is quite variable for each LUC dataset and there is no trend of variation with increasing cell size.

\begin{tabular}{|c|c|c|c|c|c|c|c|c|c|c|c|}
\hline \multirow{3}{*}{$\begin{array}{c}\text { Luc } \\
\text { Dataset }\end{array}$} & \multirow{3}{*}{$\begin{array}{c}\begin{array}{c}\text { Vector } \\
\text { GI }\end{array} \\
\mathbf{k m}^{2}\end{array}$} & \multicolumn{10}{|c|}{ Raster Area Variation Relatively to Vector GI } \\
\hline & & \multicolumn{2}{|c|}{ R $10 \mathrm{~m}$} & \multicolumn{2}{|c|}{ R $25 \mathrm{~m}$} & \multicolumn{2}{|c|}{ R $50 \mathrm{~m}$} & \multicolumn{2}{|c|}{$\mathrm{R} 100 \mathrm{~m}$} & \multicolumn{2}{|c|}{ R $200 \mathrm{~m}$} \\
\hline & & $\%$ & $\mathrm{~km}^{2}$ & $\%$ & $\mathrm{~km}^{2}$ & $\%$ & $\mathrm{~km}^{2}$ & $\%$ & $\mathrm{~km}^{2}$ & $\%$ & $\mathrm{~km}^{2}$ \\
\hline $\cos$ & $88,962.5$ & $-2.4^{-05}$ & -0.022 & $8.8^{-05}$ & 0.079 & $-1.0^{-04}$ & -0.091 & $2.6^{-04}$ & 0.234 & $-2.6^{-04}$ & -0.236 \\
\hline CLC & $88,962.5$ & $-5.1^{-06}$ & -0.005 & $7.0^{-05}$ & 0.062 & $2.0^{-04}$ & 0.179 & $-3.7^{-04}$ & -0.326 & $-1.8^{-05}$ & -0.016 \\
\hline
\end{tabular}

Table 3. Area of mainland Portugal in vector GI and area variation after vector-to-raster conversion.

It was also observed that the area loss shown by the COS in raster format with high resolution $(10 \mathrm{~m})$ relative to the vector is higher when compared to the area loss observed in the CLC dataset 
at the same resolution. Different results are obtained when using the $25 \mathrm{~m}$ resolution. In this case, both outputs feature a gain in area, especially for the COS dataset. In the output, when using $50 \mathrm{~m}$ resolution, the area loss in COS and the gain in CLC are remarkable, but for the $100 \mathrm{~m}$ outputs the reverse situation was observed. For the low-resolution raster $(200 \mathrm{~m})$, the high area loss in COS relative to CLC stands out.

These differences in area between raster outputs can be related to the cell assignment type selected ("cell center"), where the polygon that overlaps the center of the cell yields the attribute to assign to the cell. According to Bolstad [77], "raster cell assignment may be complicated when representing what we typically think of as discrete boundaries, for example, when the raster value is interpreted as a class code or as a contiguous region ID". According to this author, the type of assignment rules may significantly alter the data layer.

\subsection{LUC at Different Raster Resolutions}

The areas occupied by the LUC types in the study area vary widely, mostly for the classes with higher percentage of area: "Scrub and/or herbaceous vegetation associations, forests, agricultural areas and arable land heterogeneous". However, a general analysis of the results presented in Table 4 shows a discrepancy between the areas of each LUC class and an inconsistency between some trends of absolute variation between areas for the first and last years of each LUC. For example, the COS presents a trend toward an area reduction in the class "scrub and/or herbaceous vegetation associations", while for the CLC the trend is toward an increase in area.

Table 4. Area of LUC classes (\% of mainland Portugal, $88,962.5 \mathrm{~km}^{2}$ ) obtained by vector GI and raster outputs with different resolutions for the different years, by each LUC dataset (COS and CLC).

\begin{tabular}{|c|c|c|c|c|c|c|c|c|c|c|c|c|}
\hline \multirow{3}{*}{$\begin{array}{c}\text { LUC } \\
\text { COS (Years) } \\
\end{array}$} & \multirow{2}{*}{\multicolumn{2}{|c|}{ Vector GI }} & \multicolumn{10}{|c|}{ Raster GI } \\
\hline & & & \multicolumn{2}{|c|}{$\mathrm{R} 10 \mathrm{~m}$} & \multicolumn{2}{|c|}{ R $25 \mathrm{~m}$} & \multicolumn{2}{|c|}{ R $50 \mathrm{~m}$} & \multicolumn{2}{|c|}{ R $100 \mathrm{~m}$} & \multicolumn{2}{|c|}{ R $200 \mathrm{~m}$} \\
\hline & 2007 & 2010 & 2007 & 2010 & 2007 & 2010 & 2007 & 2010 & 2007 & 2010 & 2007 & 2010 \\
\hline 11. Urban fabric & 3.30 & 3.34 & 3.30 & 3.34 & 3.30 & 3.34 & 3.30 & 3.34 & 3.30 & 3.34 & 3.31 & 3.34 \\
\hline 12. Industrial, commercial and transport units & 1.03 & 1.11 & 1.03 & 1.11 & 1.03 & 1.11 & 1.03 & 1.10 & 1.03 & 1.10 & 1.03 & 1.10 \\
\hline 13. Mine, dump, and construction sites & 0.35 & 0.39 & 0.35 & 0.39 & 0.35 & 0.39 & 0.36 & 0.39 & 0.36 & 0.39 & 0.35 & 0.39 \\
\hline 14. Artificial, non-agricultural vegetated areas & 0.16 & 0.17 & 0.16 & 0.17 & 0.16 & 0.17 & 0.16 & 0.17 & 0.16 & 0.17 & 0.16 & 0.17 \\
\hline 21. Arable land & 13.43 & 13.25 & 13.43 & 13.25 & 13.43 & 13.25 & 13.43 & 13.25 & 13.42 & 13.24 & 13.43 & 13.25 \\
\hline 22. Permanent $\mathrm{cr}$ & 8.09 & 8.28 & 8.09 & 8.28 & 8.09 & 8.28 & 8.09 & 8.28 & 8.09 & 8.28 & 8.09 & 8.28 \\
\hline 23. Pastures & 4.64 & 4.51 & 4.64 & 4.51 & 4.64 & 4.51 & 4.64 & 4.51 & 4.64 & 4.51 & 4.64 & 4.51 \\
\hline 24. Heterogeneous agricultural areas & 13.54 & 13.54 & 13.54 & 13.54 & 13.54 & 13.54 & 13.54 & 13.54 & 13.54 & 13.54 & 13.56 & 13.56 \\
\hline 31. Forests & 24.32 & 24.46 & 24.32 & 24.46 & 24.32 & 24.46 & 24.32 & 24.46 & 24.32 & 24.45 & 24.31 & 24.45 \\
\hline 32. Scrub an & 28.13 & 26.86 & 28.13 & 26.86 & 28.13 & 26.86 & 28.13 & 26.86 & 28.14 & 26.86 & 28.12 & 26.84 \\
\hline 33. Ope & 0.89 & 1.97 & 0.89 & 1.97 & 0.89 & & 0.89 & 1.97 & 0.89 & 1.97 & 0.89 & 1.97 \\
\hline 41. Inland wetlands & 0.04 & 0.04 & 0.04 & 0.04 & 0.04 & 0.04 & 0.04 & 0.04 & 0.04 & 0.04 & 0.04 & 0.04 \\
\hline 42. Maritime wetlands & 0.28 & 0.28 & 0.28 & 0.28 & 0.28 & 0.28 & 0.28 & 0.28 & 0.28 & 0.28 & 0.28 & 0.28 \\
\hline 51. I & 1.25 & 1.27 & 1.25 & 1.27 & 1.25 & 1.27 & 1.25 & 1.27 & 1.25 & 1.27 & 1.25 & 1.27 \\
\hline 52. Marine waters & 0.54 & 0.54 & 0.54 & 0.54 & 0.54 & 0.54 & 0.54 & 0.54 & 0.54 & 0.54 & 0.55 & 0.55 \\
\hline CLC (Years) & 2006 & 2012 & 2006 & 2012 & 2006 & 2012 & 2006 & 2012 & 2006 & 2012 & 2006 & 2012 \\
\hline 11. Ur & 5 & 2.7 & 25 & 2.7 & 2.5 & 2.7 & 2.56 & 2.7 & 2.5 & 2.7 & 2.56 & 2.70 \\
\hline 12. Industr & 0.53 & 0.62 & 0.53 & 0.62 & 0.53 & 0.62 & 0.53 & 0.62 & 0.53 & 0.62 & 0.53 & 0.62 \\
\hline 13. Mine, dump, and cons & 0.24 & 0.23 & 0.24 & 0.23 & 0.24 & 0.23 & 0.24 & 0.23 & 0.24 & 0.23 & 0.24 & 0.23 \\
\hline 14. Artificial, non-agricultural vegetated areas & 0.15 & 0.19 & 0.15 & 0.19 & 0.15 & 0.19 & 0.15 & 0.19 & 0.15 & 0.19 & 0.15 & 0.19 \\
\hline 21. Arable land & 13.99 & 12.74 & 13.99 & 12.74 & 13.99 & 12.74 & 13.99 & 12.74 & 14.00 & 12.74 & 13.99 & 12.74 \\
\hline 22. Permanent crops & 6.67 & 7.08 & 6.67 & 7.08 & 6.67 & 7.08 & 6.67 & 7.08 & 6.66 & 7.08 & 6.66 & 7.09 \\
\hline 23. Pastures & 0.47 & 0.70 & 0.47 & 0.70 & 0.47 & 0.70 & 0.47 & 0.70 & 0.47 & 0.70 & 0.47 & 0.70 \\
\hline 24. Heterogeneous agricu & 26.07 & 26.35 & 26.07 & 26.35 & 26.07 & 26.35 & 26.07 & 26.35 & 26.07 & 26.35 & 26.07 & 26.35 \\
\hline 31. Forests & 22.67 & 22.71 & 22.67 & 22.71 & 22.67 & 22.71 & 22.67 & 22.71 & 22.66 & 22.71 & 22.68 & 22.72 \\
\hline 32. Scrub an & 23.32 & 23.64 & 23.32 & 23.64 & 23.32 & 23.64 & 23.32 & 23.64 & 23.32 & 23.65 & 23.31 & 23.64 \\
\hline th little or no vegetation & 1.90 & 1.52 & 1.90 & 1.52 & 1.90 & 1.52 & 1.90 & 1.52 & 1.90 & 1.51 & 1.90 & 1.52 \\
\hline 41. Inland wetlands & 0.82 & 0.89 & 0.82 & 0.89 & 0.82 & 0.89 & 0.82 & 0.89 & 0.82 & 0.89 & 0.81 & 0.88 \\
\hline 42. Maritime wetlands & 0.31 & 0.30 & 0.31 & 0.30 & 0.31 & 0.30 & 0.31 & 0.30 & 0.31 & 0.30 & 0.31 & 0.30 \\
\hline 51. Inland waters & 0.01 & 0.01 & 0.01 & 0.01 & 0.01 & 0.01 & 0.01 & 0.01 & 0.01 & 0.01 & 0.01 & 0.01 \\
\hline 52. Marine waters & 0.31 & 0.31 & 0.31 & 0.31 & 0.31 & 0.31 & 0.31 & 0.31 & 0.31 & 0.31 & 0.31 & 0.31 \\
\hline
\end{tabular}

The different LUCC observed can be explained by the different properties of each LUC dataset under analysis. Furthermore, there may be changes in LUCC trends as a function of the analysis period, i.e., on the assumption that the COS covers only part of the total period between each CLC (three of the six years), in the total period between the CLC datasets (six years) the tendency of LUCC observed in the first three years, corresponding to the COS period, may be different than what occurred in the 
last three years of the period. The same thing could happen for the results of the CLC if we consider the same period between each COS (three years), i.e., the area of a LUC type can increase or reduce, and this result is not exactly equal to what is observed for the LUCC obtained with the COS.

In the process of vector to raster GI conversion, the bigger the cell size, the greater the generalization of the represented GI [63,78], which is widely acknowledged in this type of GIS conversion. Figure 4 represents a LUC extract for each LUC dataset, where this generalization is shown. This extract was selected since it allows us to show concrete examples of generalization in different raster outputs. Classes with bigger area, e.g., water bodies, but with great variation in the shape of polygons result in different aggregations in the vector-to-raster conversion (e.g., the Zêzere River loses representativeness at low resolution), but on the other hand, some effects of generalization in polygons with reduced area, e.g., in the class urban fabric of COS, can also be noted. Major changes are visible for the sample with lower resolution (larger cell size), as well as the amalgamation and dilation of LUC GI (e.g., scrub and/or herbaceous vegetation associations and heterogeneous agricultural areas). Other LUC types, such as water course (Zêzere River) or heterogeneous agricultural areas, are not represented in the low-resolution raster (greater than $100 \mathrm{~m}$ cells), because of their reduced area in determined segments and the relatively small distance between lines (riverbanks in the case of the Zêzere River). The errors of area (polygon) conversions and the effects of polygon size and shape and raster cell size are described in some studies [79-81].
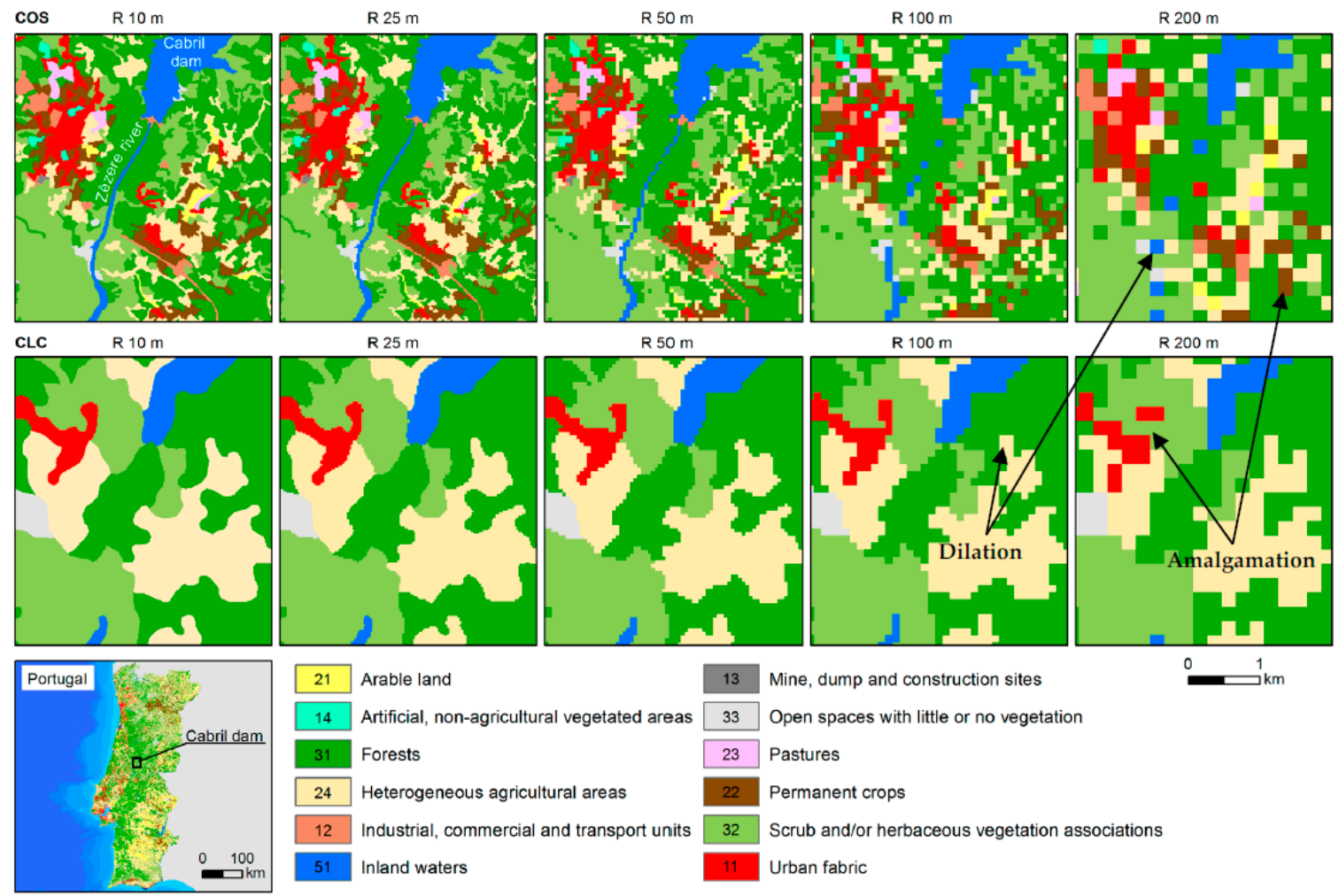

Figure 4. LUC extracts with different resolutions (COS 2010 and CLC 2012) in the central region of Portugal (downstream of Cabril Dam).

Comparing the COS and CLC outputs for different resolutions, the COS outputs are more spatially complex (see example in Figure 4), mainly due to the greater detail of the GI in this LUC dataset (minimum mapping unit (MMU) 1 ha). COS allows the spatial representation of more LUC classes compared to CLC (because of the inherent scale of the GI). This is one of the characteristics that also contributed to the greater dispersion of LUC in the samples of COS represented in Figure 4. The processes of amalgamation and dilation can be more important, due to the form and area of each polygon of LUC, and the distance (proximity or remoteness) between polygons with the same attribute. 
The CLC vector dataset, due to its inherent characteristics/specifications, has greater generalization of LUC than the COS vector dataset. According to Yang et al. [82], generalization of the LUC GI cannot dispense with the aggregation and amalgamation operations of the patch polygons.

Relative and absolute changes between the total area for each LUC type in the different outputs for different raster resolutions (per year) vary widely (Figure 5), being more significant as cell size increases.

Some LUC types present bigger areal difference in relation to the area measured in the vector GI when the cell size increases (Table 5). However, these differences are not common between the LUC datasets considered in the analysis, or even between the outputs with different resolutions. For example, in the case of COS, there is an increase of $0.01 \%$ in urban area in the $200 \mathrm{~m}$ raster output, while in the class "Industrial, commercial and transport units", there is a loss of area, but the same cannot be observed in the outputs of the CLC.

Table 5. Main variation areas (gain $\geq 0.01 \%$ and loss $\leq-0.01 \%$ of mainland Portugal) of the LUC raster (COS 2007 and 2010; CLC 2006 and 2012) relative to LUC areas in vector GI.

\begin{tabular}{|c|c|c|c|c|c|c|}
\hline LUC & \multicolumn{2}{|c|}{$\operatorname{COS}(\mathrm{R} 100 \mathrm{~m})$} & \multicolumn{2}{|c|}{ COS (R $200 \mathrm{~m})$} & \multicolumn{2}{|c|}{ CLC (R $200 \mathrm{~m})$} \\
\hline 11. Urban fabric & 0.00 & 0.00 & 0.01 & 0.00 & 0.00 & 0.00 \\
\hline 21. Arable land & -0.01 & -0.01 & 0.00 & 0.00 & 0.00 & 0.00 \\
\hline 22. Permanent crops & 0.00 & 0.00 & 0.00 & 0.00 & 0.00 & 0.01 \\
\hline 24. Heterogeneous agricultural areas & 0.00 & 0.00 & 0.02 & 0.02 & 0.00 & 0.00 \\
\hline
\end{tabular}

In the outputs at low resolution (pixel size greater than $100 \mathrm{~m}$ ), there were LUC classes that showed breaks in the variation trend compared to those observed in outputs with higher resolution $(10,25$, or even $50 \mathrm{~m})$. This reversal of area variation for each LUC type (Figure 5), among the different resolutions, is not equal or similar in the different years for the same LUC dataset. This variation can be explained by LUCC that occurred in the period between each LUC data acquisition year, but also because of the different effects that occur in the vector-to-raster conversion process.

LUC classes with reduced area (for example, inland and maritime wetlands, and inland and marine waters) show the highest relative changes for different raster resolutions, and they are more significant at low resolution $(200 \mathrm{~m})$.

\subsection{LUCC at Different Raster Resolution Levels}

LUCC in mainland Portugal are very distinct between the different LUC types. In absolute terms, the most important LUCC show high loss and gain of area in the classes "forest and scrub and/or herbaceous vegetation associations" of the COS results (2007 to 2010), and for the same classes in the results obtained by the CLC (2006 to 2012), but in this last dataset the "heterogeneous agricultural areas" also show relevant area changes (Table 6). These results are consistent with LUCC presented by other research $[22,39,72]$. 

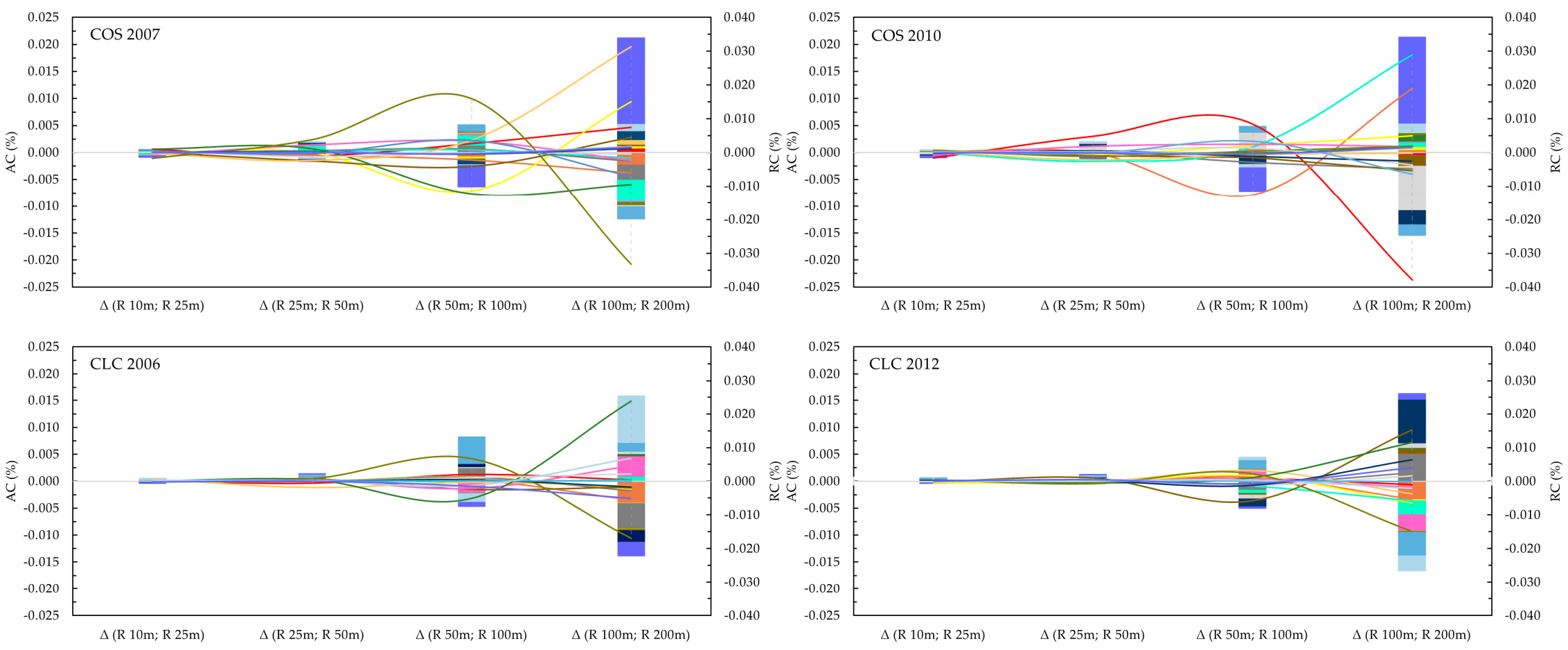

Absolute Changes (AC)

Urban fabric

$$
\text { - Permanent crops }
$$

Open spaces with little or no vegetatio

$$
\text { - Pastures }
$$

Maritime wetlands

- Heterogeneous agricultural areas

- Inland wetlands

Relative Changes (RC)

Urban fabric

Industrial, commercial and transport units

Pastures

Maritime wetlands

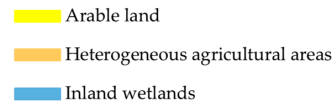

Inland wetlands
— Mine, dump and construction sites

- Forests

Marine waters

Mine, dump and construction sites

Fores

Marine water
— Artificial, non-agricultural vegetated areas

- Scrub and/or herbaceous vegetation associations

— Inland waters

Artificial, non-agricultural vegetated areas

Scrub and/or herbaceous vegetation association Inland waters

Figure 5. Absolute and relative change variation (\% area) between LUC geoinformation with different resolutions ( $R$, raster resolution in meters). 
Table 6. Gain and loss area (\% of mainland Portugal) by LUC type (absolute changes), obtained for different raster resolutions outputs. Values in bold represent above average gain and loss areas for each dataset (COS and CLC).

\begin{tabular}{|c|c|c|c|c|c|c|c|c|c|c|c|c|c|}
\hline & \multirow[b]{2}{*}{ LUC } & \multicolumn{2}{|c|}{ Vector Data } & \multicolumn{2}{|c|}{$\mathrm{R} 10 \mathrm{~m}$} & \multicolumn{2}{|c|}{ R $25 \mathrm{~m}$} & \multicolumn{2}{|c|}{ R $50 \mathrm{~m}$} & \multicolumn{2}{|c|}{ R $100 \mathrm{~m}$} & \multicolumn{2}{|c|}{ R $200 \mathrm{~m}$} \\
\hline & & Loss & Gain & Loss & Gain & Loss & Gain & Loss & Gain & Loss & Gain & Loss & Gain \\
\hline \multirow{15}{*}{ 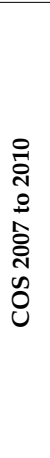 } & 11. Urban fabric & -0.0021 & 0.0386 & -0.0021 & 0.0386 & -0.0021 & 0.0385 & -0.0021 & 0.0388 & -0.0021 & 0.0385 & -0.0023 & 0.0371 \\
\hline & 12. Industrial, commercial and transport units & -0.0019 & 0.0753 & -0.0019 & 0.0752 & -0.0019 & 0.0753 & -0.0019 & 0.0752 & -0.0020 & 0.0758 & -0.0020 & 0.0762 \\
\hline & 13. Mine, dump and construction sites & -0.0653 & 0.1017 & -0.0653 & 0.1017 & -0.0652 & 0.1016 & -0.0654 & 0.1018 & -0.0662 & 0.1013 & -0.0652 & 0.1003 \\
\hline & 14. Artificial, non-agricultural vegetated areas & -0.0008 & 0.0164 & -0.0008 & 0.0164 & -0.0008 & 0.0163 & -0.0008 & 0.0164 & -0.0008 & 0.0167 & -0.0007 & 0.0153 \\
\hline & 21. Arable land & -0.4373 & 0.2549 & -0.4373 & 0.2549 & -0.4372 & 0.2550 & -0.4373 & 0.2550 & -0.4381 & 0.2550 & -0.4370 & 0.2563 \\
\hline & 22. Permanent crops & -0.1733 & 0.3631 & -0.1733 & 0.3631 & -0.1733 & 0.3632 & -0.1731 & 0.3631 & -0.1730 & 0.3652 & -0.1742 & 0.3635 \\
\hline & 23. Pastures & -0.2227 & 0.0910 & -0.2226 & 0.0910 & -0.2226 & 0.0910 & -0.2228 & 0.0909 & -0.2233 & 0.0909 & -0.2205 & 0.0907 \\
\hline & 24. Heterogeneous agricultural areas & -0.1677 & 0.1668 & -0.1677 & 0.1667 & -0.1677 & 0.1668 & -0.1678 & 0.1667 & -0.1684 & 0.1661 & -0.1699 & 0.1661 \\
\hline & 31. Forests & -1.5494 & 1.6818 & -1.5493 & 1.6817 & -1.5496 & 1.6816 & -1.5496 & 1.6810 & -1.5458 & 1.6830 & -1.5485 & 1.6887 \\
\hline & 32. Scrub and/or herbaceous vegetation associations & -2.6999 & 1.4263 & -2.6999 & 1.4263 & -2.6997 & 1.4262 & -2.6993 & 1.4264 & -2.7030 & 1.4253 & -2.7074 & 1.4268 \\
\hline & 33. Open spaces with little or no vegetation & -0.0876 & 1.1690 & -0.0875 & 1.1690 & -0.0875 & 1.1692 & -0.0875 & 1.1692 & -0.0874 & 1.1694 & -0.0881 & 1.1715 \\
\hline & 41. Inland wetlands & 0.0000 & 0.0001 & 0.0000 & 0.0001 & 0.0000 & 0.0001 & 0.0000 & 0.0001 & 0.0000 & 0.0000 & 0.0000 & 0.0000 \\
\hline & 42. Maritime wetlands & -0.0001 & 0.0001 & -0.0001 & 0.0001 & -0.0002 & 0.0001 & -0.0002 & 0.0001 & -0.0001 & 0.0001 & -0.0001 & 0.0001 \\
\hline & 51. Inland waters & -0.0005 & 0.0237 & -0.0005 & 0.0237 & -0.0005 & 0.0237 & -0.0005 & 0.0237 & -0.0006 & 0.0236 & -0.0004 & 0.0238 \\
\hline & 52. Marine waters & -0.0001 & 0.0000 & -0.0001 & 0.0000 & -0.0001 & 0.0000 & -0.0001 & 0.0000 & 0.0000 & 0.0000 & -0.0001 & 0.0000 \\
\hline \multirow{15}{*}{ 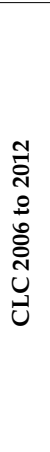 } & 11. Urban fabric & -0.0958 & 0.2387 & -0.0958 & 0.2387 & -0.0959 & 0.2387 & -0.0955 & 0.2387 & -0.0959 & 0.2384 & -0.0971 & 0.2387 \\
\hline & 12. Industrial, commercial and transport units & -0.0401 & 0.1303 & -0.0401 & 0.1303 & -0.0401 & 0.1303 & -0.0401 & 0.1301 & -0.0400 & 0.1306 & -0.0401 & 0.1310 \\
\hline & 13. Mine, dump and construction sites & -0.0867 & 0.0796 & -0.0867 & 0.0796 & -0.0867 & 0.0796 & -0.0868 & 0.0797 & -0.0873 & 0.0800 & -0.0860 & 0.0794 \\
\hline & 14. Artificial, non-agricultural vegetated areas & -0.0046 & 0.0451 & -0.0046 & 0.0451 & -0.0046 & 0.0451 & -0.0046 & 0.0452 & -0.0046 & 0.0447 & -0.0044 & 0.0459 \\
\hline & 21. Arable land & -1.9297 & 0.6756 & -1.9297 & 0.6755 & -1.9298 & 0.6755 & -1.9299 & 0.6753 & -1.9302 & 0.6759 & -1.9267 & 0.6700 \\
\hline & 22. Permanent crops & -0.5920 & 1.0107 & -0.5920 & 1.0107 & -0.5920 & 1.0108 & -0.5919 & 1.0108 & -0.5924 & 1.0092 & -0.5885 & 1.0159 \\
\hline & 23. Pastures & -0.1106 & 0.3395 & -0.1106 & 0.3395 & -0.1107 & 0.3396 & -0.1106 & 0.3396 & -0.1099 & 0.3395 & -0.1110 & 0.3387 \\
\hline & 24. Heterogeneous agricultural areas & -1.9740 & 2.2551 & -1.9739 & 2.2550 & -1.9740 & 2.2549 & -1.9737 & 2.2557 & -1.9723 & 2.2564 & -1.9724 & 2.2552 \\
\hline & 31. Forests & -2.9602 & 3.0069 & -2.9602 & 3.0069 & -2.9602 & 3.0069 & -2.9604 & 3.0066 & -2.9593 & 3.0093 & -2.9672 & 3.0095 \\
\hline & 32. Scrub and/or herbaceous vegetation associations & -3.6996 & 4.0261 & -3.6996 & 4.0262 & -3.6994 & 4.0263 & -3.6996 & 4.0256 & -3.7032 & 4.0263 & -3.7003 & 4.0247 \\
\hline & 33. Open spaces with little or no vegetation & -0.6575 & 0.2772 & -0.6575 & 0.2772 & -0.6575 & 0.2772 & -0.6574 & 0.2773 & -0.6588 & 0.2776 & -0.6571 & 0.2770 \\
\hline & 41. Inland wetlands & -0.0090 & 0.0774 & -0.0090 & 0.0774 & -0.0090 & 0.0775 & -0.0090 & 0.0774 & -0.0088 & 0.0772 & -0.0091 & 0.0771 \\
\hline & 42. Maritime wetlands & -0.0089 & 0.0057 & -0.0089 & 0.0057 & -0.0090 & 0.0057 & -0.0089 & 0.0057 & -0.0090 & 0.0057 & -0.0093 & 0.0057 \\
\hline & 51. Inland waters & -0.0020 & 0.0020 & -0.0020 & 0.0020 & -0.0020 & 0.0020 & -0.0020 & 0.0020 & -0.0020 & 0.0019 & -0.0022 & 0.0019 \\
\hline & 52. Marine waters & -0.0016 & 0.0023 & -0.0016 & 0.0023 & -0.0016 & 0.0023 & -0.0016 & 0.0023 & -0.0015 & 0.0023 & -0.0019 & 0.0025 \\
\hline
\end{tabular}


However, the LUCC results are not coherent among themselves when using the different resolutions of the two raster datasets considered in this research. The area loss or gain between different raster resolutions is very variable for different LUC classes. For example, in the COS LUCC results, the area loss in the forest class using the $25 \mathrm{~m}$ resolution, relative to vector GI, presents a slight increase, but when using $100 \mathrm{~m}$ raster resolution there is a slight reduction of area. The results for the forest class obtained with low resolution $(200 \mathrm{~m})$ again show an area loss. The reverse situation is observed for higher resolutions, where there is a reduction in area increase when cell size increases, but this situation is inverted for resolutions equal to or higher than $100 \mathrm{~m}$. In these cases, the output raster provides the GI generalization and is conducive to accurate and classification errors with the increase in cell size, but a solution to reduce this error is to increment the resolution, i.e., increase the number of cells (high resolution, small cells) [78]. Several other studies also reference the errors associated with vector-to-raster conversions and vice versa [83-85].

The differences in area for each LUC type presented in Table 6 are very small in terms of percentage, but these values represent several hectares in the study area $(1 \% \approx 88,971.3 \mathrm{ha})$, and thus some care is required in the analysis of results.

Crossing factors $\mathrm{K}_{\mathrm{c}}$ and $\mathrm{PA}_{\mathrm{Rt}}$ with absolute and relative variations of vector GI verses different resolution outputs, only the relative variations present a few significant correlations with these factors (Table 7). A more detailed analysis of these results highlights the high positive correlation between the CLC with $P A_{R t}$ (except RC Vet/R200 of CLC12), while $K_{c}$ presents only a high correlation between the relative variations on lower resolution verses vector GI (RV Vet/R200).

Table 7. Correlation coefficients between $\mathrm{K}_{\mathrm{c}}$ average, $\mathrm{PA}_{\mathrm{Rt}}$, and relative variations (RV) area of the vector GI (Vet) verses different resolution (R) outputs (significance level $p<0.05$ ).

\begin{tabular}{ccccccc}
\hline LUC Dataset & Variable & RV Vet/R10 & RV Vet/R25 & RV Vet/R50 & RV Vet/R100 & RV Vet/R200 \\
\hline \multirow{2}{*}{ CLC06 } & $\mathrm{K}_{\mathrm{c}}$ & -0.28 & 0.58 & 0.41 & -0.11 & 0.71 \\
& $\mathrm{PA}_{\mathrm{Rt}}$ & 0.84 & 0.70 & 0.71 & 0.91 & 0.55 \\
\hline \multirow{2}{*}{ CLC12 } & $\mathrm{K}_{\mathrm{c}}$ & -0.25 & 0.36 & 0.34 & -0.35 & 0.72 \\
& $\mathrm{PA}_{\mathrm{Rt}}$ & 0.96 & 0.82 & 0.68 & 0.73 & -0.24 \\
\hline \multirow{2}{*}{ COS07 } & $\mathrm{K}_{\mathrm{c}}$ & -0.54 & -0.23 & -0.54 & -0.60 & 0.68 \\
& $\mathrm{PA}_{\mathrm{Rt}}$ & 0.12 & -0.29 & 0.32 & 0.40 & -0.33 \\
\hline \multirow{2}{*}{$\operatorname{COS10}$} & $\mathrm{K}_{\mathrm{c}}$ & -0.58 & -0.27 & -0.57 & -0.56 & 0.74 \\
& $\mathrm{PA}_{\mathrm{Rt}}$ & 0.10 & -0.31 & 0.32 & 0.28 & -0.54 \\
\hline
\end{tabular}

On the other hand, analyzing the results by principal component analysis (PCA), LUC class groupings derived from relative variations of area between different raster outputs and vector GI were observed (Figure 6).

In Figure 6, Factor 1 represents the relative variations mentioned above, and Factor 2 represents the factor form of polygons and their representation/distribution by LUC classes. LUC classes with lower relative variations tend to group together (G1), as well classes with highest relative changes (G2), and a few classes that do not fit into these groups represent the very high relative variations, but also influence the factor form of the polygons. 

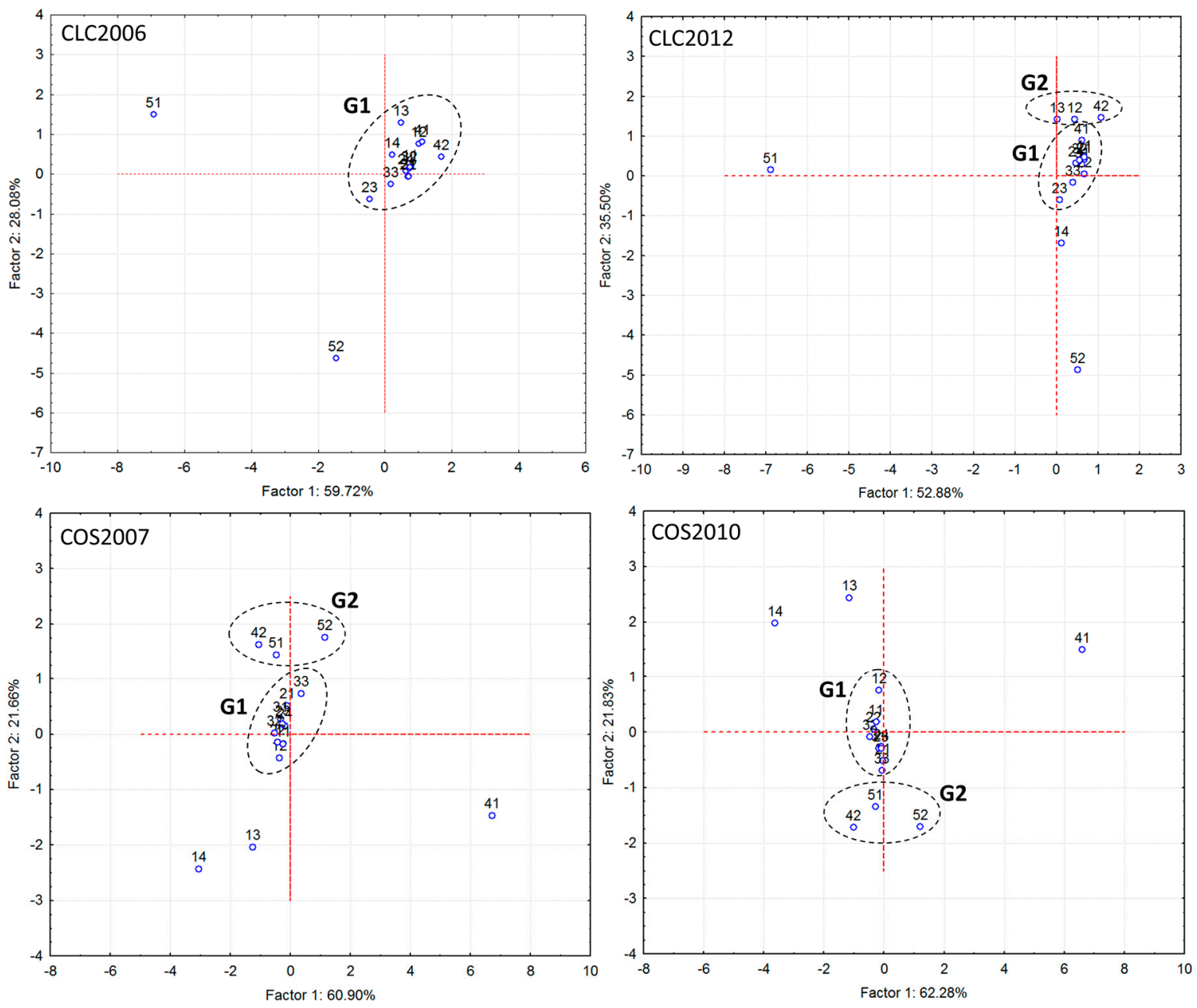

Figure 6. LUC class projection on the factor plane (LUC classes with sum of cosine squared $\geq 0$ ). LUC codes: See legend in Figure 1.

\subsection{LUCC Variations}

In the first stage and considering data inputs for this analysis, the high correlation between the total areas of LUC types (for each LUC dataset) described initially, observed at the end of each period (three and six years for the COS and CLC, respectively), are questionable, because each LUC class can have area loss, and at the same time area gain for another LUC type, balancing the area of LUC classes. However, LUCC can also occur between subclasses (level 3 in CLC, or levels 4 and 5 in COS), although they were not described in this research, and we should have some caution in interpreting the relationship between the total area observed initially and the area observed at the end of the LUCC period. In this context, it is important to analyze the confusion matrix, using classes at level 2 of the nomenclature or at more detailed levels.

The results of the total area for each LUC class of COS and CLC (Table 4) are not consistent in a temporal sequence. These results are mainly due to the different properties of the LUC datasets, although each dataset has a different data acquisition year, but coincident with a part of the total period under evaluation. The CLC, with 25 ha of minimum mapping unit (MMU) and $20 \mathrm{~m}$ of spatial resolution (SR), presents greater generalization compared to COS (MMU 1 ha; SR $0.5 \mathrm{~m}$ ). This explains the differences in area for each type of LUC in both datasets in different years.

The Portuguese territory presents great LUC fragmentation, especially in the northern region [39], where small plots ( $<25 \mathrm{ha}$ ) are predominant, and these are not identified in the CLC, while the COS, with smaller MMU and greater disaggregation of the nomenclature (five levels), enables identification 
and representation of the LUC with greater detail, and thus representation of most of these small plots (mostly agricultural parcels).

In the vector-to-raster conversion of LUC GI (cells with different sizes), some generalization of the GI occurs, which is demonstrated in this study and several others $[48,56,86]$. This generalization increases with cell size, making the results change, and the total area of each LUC type of the LUC datasets is analyzed. On the other hand, errors increased with increasing raster resolution [63] and the results presented also demonstrate this fact, especially the results at low resolution (100 and $200 \mathrm{~m}$ ).

Comparing the different raster outputs with different resolutions, in general, the variations in area for LUC types are very similar, showing a high positive correlation, but the high-resolution area of LUC shows greater resemblance to what is observed in the vector GI (Table 8). The biggest areal differences between the areas in the vector and at different raster resolutions are for resolutions bigger than $50 \mathrm{~m}$.

Table 8. Correlation coefficients between LUCC table transition areas with different resolutions (R) and vector data of CLC (bold values) and COS (significance level $p<0.05$ ).

\begin{tabular}{ccccccc}
\hline & $\mathbf{R} \mathbf{1 0} \mathbf{~ m}$ & $\mathbf{R} \mathbf{2 5} \mathbf{~ m}$ & $\mathbf{R} \mathbf{5 0 ~} \mathbf{~}$ & $\mathbf{R} \mathbf{1 0 0} \mathbf{~ m}$ & $\mathbf{R} \mathbf{2 0 0} \mathbf{~}$ & Vector \\
\hline R 10 m & 1 & 0.999999999 & 0.999999997 & 0.999999943 & 0.9999999738 & 1.000000000 \\
R 25 m & $\mathbf{1 . 0 0 0 0 0 0 0 0 0}$ & 1 & 0.999999996 & 0.999999937 & 0.999999741 & 1.000000000 \\
R 50 m & $\mathbf{1 . 0 0 0 0 0 0 0 0 0}$ & $\mathbf{0 . 9 9 9 9 9 9 9 9 9}$ & 1 & 0.999999951 & 0.999999698 & 0.999999997 \\
R 100 m & $\mathbf{0 . 9 9 9 9 9 9 9 9 2}$ & $\mathbf{0 . 9 9 9 9 9 9 9 9 2}$ & $\mathbf{0 . 9 9 9 9 9 9 9 9 1}$ & 1 & 0.999999632 & 0.999999942 \\
R 200 m & $\mathbf{0 . 9 9 9 9 9 9 9 3 5}$ & $\mathbf{0 . 9 9 9 9 9 9 9 3 5}$ & $\mathbf{0 . 9 9 9 9 9 9 9 3 4}$ & $\mathbf{0 . 9 9 9 9 9 9 9 1 3}$ & 1 & 0.999999735 \\
Vector & $\mathbf{1 . 0 0 0 0 0 0 0 0 0}$ & $\mathbf{1 . 0 0 0 0 0 0 0 0 0}$ & $\mathbf{1 . 0 0 0 0 0 0 0 0 0}$ & $\mathbf{0 . 9 9 9 9 9 9 9 9 2}$ & $\mathbf{0 . 9 9 9 9 9 9 9 3 4}$ & 1 \\
\hline
\end{tabular}

Analyzing in detail the absolute variation in area of every LUC type in each dataset and for each year, different trends can be observed in area variation when cell size increases. These differences are more evident mainly in the classes with greater area in the different LUC datasets, i.e., scrub and/or herbaceous vegetation associations and forest, except for COS 2010, where the largest variations in the class "urban fabric and industrial, commercial and transport units" are remarkable.

The urbanized land and building infrastructure (roads, industrial complexes, etc.) increased between 2007 and 2010 in mainland Portugal, and much of this LUC type is identified in the COS. However, since this LUC type is very fragmented (particularly urban fabric) and has a specific geometry, generalization of these LUC types during the vector-to-raster conversion can have variable effects. For example, with increasing cell size, two or more parcels of artificial land can be aggregated, and with a higher resolution raster this is not reflected, because of the distance between the two polygons, and their respective size. Meneses et al. [87] observed in the Zêzere watershed (central Portugal) variations in artificial land GI outputs after several vector-to-raster conversions, referencing the importance of building dimensions, especially in outputs with large cell size. Other raster effects in the generalization process can occur, e.g., simplification and displacement of buildings [88].

The differences between LUCC areas observed in this research for the same classes show the effects resulting from vector-to-raster conversions at different resolutions, but also the importance of the GI properties, especially the scale, of each LUC dataset. For example, in the LUCC analysis, the case of the component "area gain" of each LUC type in the different LUC datasets, and the COS classes with the smallest area (e.g., urban fabric; mine, dump, and construction sites; non-artificial agricultural vegetated areas), because they present, in general, lower values of area gain (in relation to the results obtained by vector GI) when increasing the cell size of the raster outputs. For more generalized LUC GI, as in the case of CLC, the classes with small area do not stand out; in this case, the "Permanent crops" class presents the highest area increase and the "Arable land" class the largest area reduction compared to the vector GI areas (Figure 7). In the component "area loss" for each LUC type, highlight in the COS dataset the smaller area loss in the class "Pastures" for the raster with 200 $\mathrm{m}$ resolution (compared to vector GI); while in CLC, the class "Permanent crops" stands out with 
the highest difference (lowest reduction) between the raster at $200 \mathrm{~m}$ and what is obtained with the vector GI.

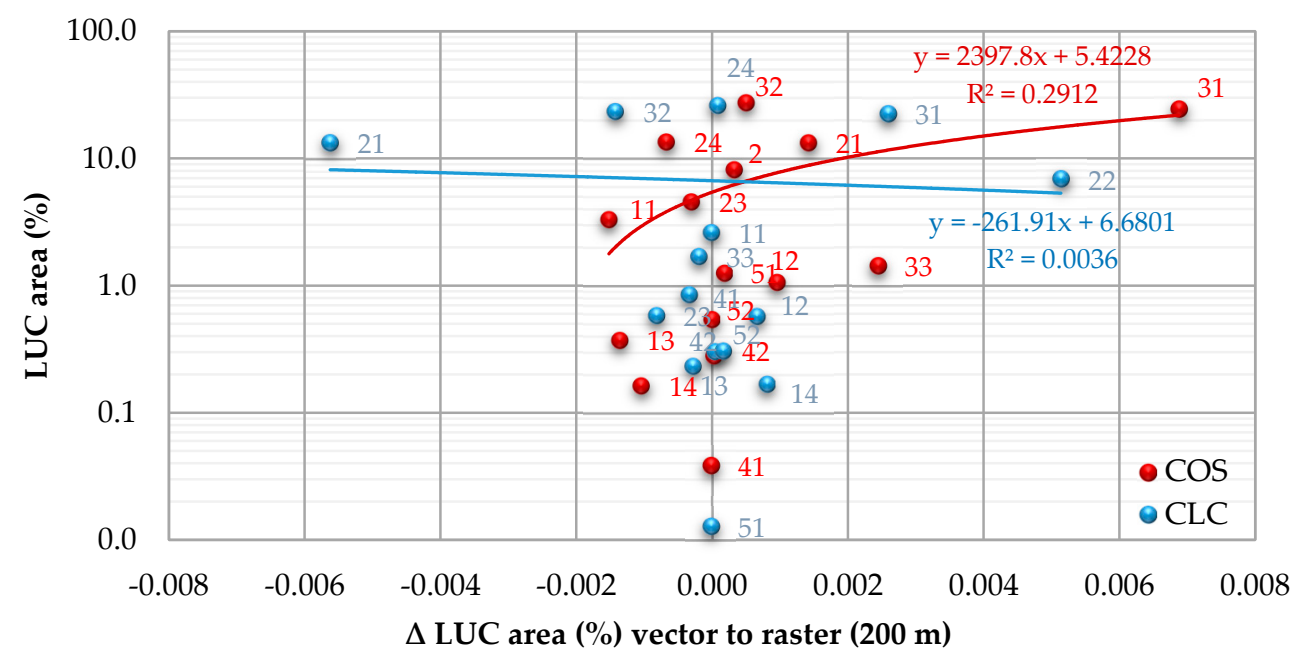

Figure 7. Relationship between LUC area (average area of vector GI: COS 2007, COS 2010; and CLC 2006, CLC 2012) and LUCC area (gains) variation obtained between vector and raster (resolution 200 $\mathrm{m})$. See LUC legend (numbers) in Figure 1.

During the vector-to-raster conversion process, the representation depends on the area, but also the form of the polygons. For example, if the area of the Zêzere River presented in Figure 4 was represented in a compact form (circle), there would be more pixels with this attribute in lower-resolution outputs. This process can be seen as evidence of the faster raster LUCC calculations and other advantages of raster GIS, but vector methods provide higher accuracy [64]. However, high-resolution raster presents results very similar to vector GI.

Jaakkola [46] researched the quality of multiscale land cover data, also using CLC GI, and reported that the generalization process reduces the complexity of the data structure and adds error to the database, therefore the quality is always deteriorated in favor of simplicity and legibility. This author also found errors produced by the generalization of raster GI and refers to the tendency for area decrease for classes covering small areas, while the classes covering large areas with large average feature size tend to suffer an area increase. In fact, these observations have been confirmed by some results obtained in this research, namely the results using CLC. These results, however, differ slightly from the results obtained with COS, where area gain and area loss are very similar using high-resolution raster, without a well-defined trend when the cell size increases. This is mainly due to the GI scale of each LUC dataset, because the COS presents, for a LUC class, more fragmented polygons (due to the $\mathrm{MMU})$, while the CLC is more generalized and presents, naturally, larger polygons.

Other authors, such as Veregin and McMaster [56], reported that changes in the thematic content of maps have implications on thematic accuracy and data quality in general. The results obtained here confirm this, because overall it was found that those datasets with the low-resolution raster (e.g., 100 and $200 \mathrm{~m}$ ) differ from the vector GI results, due to multiple effects of the vector-to-raster conversion and GI properties.

\section{Conclusions}

In mainland Portugal, large LUCC were observed in the classes "forest and scrub and/or herbaceous vegetation associations" and "heterogeneous agricultural areas." However, the LUCC results are not coherent among themselves when using the different resolutions of the two raster datasets considered (COS and CLC), and are very variable for different LUC classes. The results of the vector-to-raster conversion LUC GI (using different resolutions) show differences for LUC areas in the Portuguese territory. These results highlight the generalization of GI that occurs in these conversion 
processes. Variations of LUC area by changing the cell size of different LUC datasets (COS or CLC for several years) were observed, but these variations were not linear (which was expected in the first place) and not consistent among LUC classes in each LUC dataset, especially the outputs with a resolution equal to or higher than $100 \mathrm{~m}$.

Furthermore, different results between LUC datasets with different properties were observed. COS is more detailed than CLC, and their GI has partial temporal coincidence (for the LUC years selected), but the LUCC results obtained were different in the territory covered by this study. These results can highlight the differences in study period between the features of the LUC datasets.

The generalization that occurs in the vector-to-raster conversion process is also shown and, in this process, the importance of the inherent details of the GI vector in each LUC dataset, especially the amalgamation and dilation, form, and area of the polygons. In this sense, we stress the importance of the GI properties, because the detail is important in explaining the results obtained on LUCC determinations.

Higher resolutions of LUC GI (e.g., 10, 25, or $50 \mathrm{~m}$ ) are better for LUCC analysis in large territorial extensions, even at the scale of a country, as in this case study (mainland Portugal), because the differences observed between these raster outputs have a high correlation with results obtained by vector GI. However, $50 \mathrm{~m}$ resolution is suggested for LUCC assessment in this country, because this raster dataset with this resolution has advantages in terms of storage space compared to higher resolutions. In summary, for each case study or procedure, we should balance the efficiency of processes against the best accuracy of results.

Author Contributions: For the research presented in this paper, the individual contributions of authors are: conceptualization, B.M.M.; methodology, B.M.M.; software, B.M.M.; validation, B.M.M. and E.R.; formal analysis, B.M.M.; investigation, B.M.M. and E.R.; resources, B.M.M.; data collection, B.M.M.; writing-original draft preparation, B.M.M.; writing-review and editing, B.M.M., E.R. and R.R.; visualization, B.M.M., R.R. and M.J.V.; supervision, E.R. and M.J.V.

Funding: The work of Bruno M. Meneses was supported by a grant from Institute of Geography and Spatial Planning and Universidade de Lisboa (BD2015). Eusébio Reis was financed by national funds through FCT-Portuguese Foundation for Science and Technology, I.P., under the framework of the project FORLAND-Hydro-geomorphologic risk in Portugal: driving forces and application for land use planning (PTDC/ATPGEO/1660/2014).

Acknowledgments: The authors would like to thank the publication financing by the IGOT, Universidade de Lisboa and FCT, and the anonymous reviewers that contributed to the improvement of this paper.

Conflicts of Interest: We hereby declare that the work presented in this paper is an original research carried out by all authors. All the research stated on the paper, which has not been carried out by us, has been fully acknowledged. All appropriate ethics and other approvals have been obtained for this research. The authors declare no conflict of interest.

\section{References}

1. Ramankutty, N.; Graumlich, L.; Achard, F.; Alves, D.; Chhabra, A.; DeFries, R.S.; Foley, J.A.; Geist, H.; Houghton, R.A.; Goldewijk, K.K.; et al. Global Land-Cover Change: Recent Progress, Remaining Challenges. In Land-Use and Land-Cover Change Local Processes and Global Impacts; Lambin, E.F., Geist, H., Eds.; Springer: Berlin, Germany, 2006; pp. 9-70.

2. Charney, J.; Stone, P.H.; Quirk, W.J. Drought in the Sahara: A biogeophysical feedback mechanism. Science 1975, 187, 434-435. [CrossRef] [PubMed]

3. Otterman, J. Baring high-albedo soils by overgrazing: A hypothesized desertification mechanism. Science 1974, 186, 531-533. [CrossRef] [PubMed]

4. Yang, X.; Ren, L.; Singh, V.P.; Liu, X.; Yuan, F.; Jiang, S.; Yong, B. Impacts of land use and land cover changes on evapotranspiration and runoff at Shalamulun River watershed, China. Hydrol. Res. 2012, 43, $23-37$. [CrossRef]

5. Song, W.; Deng, X. Land-use/land-cover change and ecosystem service provision in China. Sci. Total Environ. 2017, 576, 705-719. [CrossRef] [PubMed] 
6. Tasser, E.; Leitinger, G.; Tappeiner, U. Climate change versus land-use change-What affects the mountain landscapes more? Land Use Policy 2017, 60, 60-72. [CrossRef]

7. Bebi, P.; Seidl, R.; Motta, R.; Fuhr, M.; Firm, D.; Krumm, F.; Conedera, M.; Ginzler, C.; Wohlgemuth, T.; Kulakowski, D. Changes of forest cover and disturbance regimes in the mountain forests of the Alps. For. Ecol. Manag. 2016, in press.

8. Cebecauer, T.; Hofierka, J. The consequences of land-cover changes on soil erosion distribution in Slovakia. Geomorphology 2008, 98, 187-198. [CrossRef]

9. Gebresamuel, G.; Singh, B.R.; Dick, Ø. Land-use changes and their impacts on soil degradation and surface runoff of two catchments of Northern Ethiopia. Acta Agric. Scand. Sect. B Plant Soil Sci. 2010, 60, 211-226. [CrossRef]

10. Tadesse, L.; Suryabhagavan, K.V.; Sridhar, G.; Legesse, G. Land use and land cover changes and Soil erosion in Yezat Watershed, North Western Ethiopia. Int. Soil Water Conserv. Res. 2017, 5, 85-94. [CrossRef]

11. Hartemink, A.E. Land use change in the tropics and its effect on soil fertility. In Proceedings of the 19th World Congress of Soil Science, Soil Solutions for a Changing World, Brisbane, Australia, 1-6 August 2010; World Congress of Soil Science: Brisbane, Australia, 2010; Volume 1990, pp. 55-58.

12. Foley, J.A.; Ramankutty, N.; Brauman, K.A.; Cassidy, E.S.; Gerber, J.S.; Johnston, M.; Mueller, N.D.; O'Connell, C.; Ray, D.K.; West, P.C.; et al. Solutions for a cultivated planet. Nature 2011, 478, 337-342. [PubMed]

13. Petz, K. Mapping and Modelling the Effects of Land Use and Land Management Change on Ecosystem Services: From Local Ecosystems and Landscapes to Global Biomes; Wageningen University: Wageningen, NL, USA, 2014.

14. Fichera, C.R.; Modica, G.; Pollino, M. Land Cover classification and change-detection analysis using multi-temporal remote sensed imagery and landscape metrics. Eur. J. Remote Sens. 2012, 45, 1-18. [CrossRef]

15. Carpio, A.J.; Oteros, J.; Tortosa, F.S.; Guerrero-Casado, J. Land use and biodiversity patterns of the herpetofauna: The role of olive groves. Acta Oecol. 2016, 70, 103-111. [CrossRef]

16. European Union-Eurostat (Online Publications) Land Cover and Land Use. Available online: http:/ / ec. europa.eu/eurostat/statistics-explained/index.php/Land_cover_and_land_use (accessed on 27 July 2018).

17. EEA (European Environment Agency). Landscapes in Transition: An Account of 25 Years of Land Cover Change in Europe; EEA: Luxembourg, 2017.

18. European Commission Land Use Change. Available online: https://ec.europa.eu/energy/en/topics/ renewable-energy/biofuels/land-use-change (accessed on 30 June 2018).

19. Meneses, B.M.; Vale, M.J.; Reis, R.; Saraiva, R. Metodologias para a avaliação das alterações do uso e ocupação do solo em Portugal Continental nas últimas três décadas. CIDADES Comunidades Territ. 2013, 27, 50-60. [CrossRef]

20. Meneses, B.M.; Vale, M.J.; Reis, R. Uso e ocupação do solo. In Uso e Ocupação do Solo em Portugal Continental: Avaliação e Cenários Futuros, Projeto LANDYN; Direção Geral do Território, Ed.; Direção-Geral do Território: Lisboa, Portugal, 2014; pp. 16-52.

21. DGT (Directorate General of Traffic). LANDYN-Alterações de Uso e Ocupação do Solo em Portugal Continental: Caracterização, Forças Motrizes e Cenários Futuros. Relatório Anual 2012-2013; DGT: Lisboa, Portugal, 2013.

22. Meneses, B.M.; Reis, E.; Pereira, S.; Vale, M.; Reis, R. Understanding Driving Forces and Implications Associated with the Land Use and Land Cover Changes in Portugal. Sustainability 2017, 9, 351. [CrossRef]

23. Meneses, B.M.; Vale, M.J.; Reis, R.; Marrecas, P.; Barreira, E. Metodologias para a avaliação do uso e ocupação do solo em diferentes épocas. In Uso e Ocupação do Solo em Portugal Continental: Avaliação e Cenários Futuros, Projeto LANDYN; DGT, Ed.; Direção-Geral do Território: Lisboa, Portugal, 2014; pp. 5-16.

24. Nunes, V. Comparação Entre Cartografias de Ocupação e ou Uso do Solo Para a Produção de um Mapa de Incerteza Temática. Ph.D. Thesis, Instituto Superior de Estatística e Gestão de Informação da Universidade Nova de Lisboa, Lisbon, Portugal, 2008.

25. IGP. Carta de Uso e Ocupação do Solo de Portugal Continental para 2007 (COS2007), 1st ed.; Memória Descritiva; Instituto Geográfico Português/Direção Geral do Território: Lisboa, Portugal, 2010.

26. Gil, A.; Abadi, M. Using very high resolution satellite imagery for land cover mapping in Pico da Vara nature reserve (S. Miguel Island, Archipelago of the Azores, Portugal). In Proceedings of the 2015 IEEE International Geoscience and Remote Sensing Symposium (IGARSS), Milan, Italy, 26-31 July 2015; pp. 3329-3332. 
27. Santos, T.; Tenedório, J.A.; Rocha, J.; Encarnação, S. SATSTAT: Exploratory Analysis of Envisat-MERIS Data for Land Cover Mapping of Portugal in 2003. In Proceedings of the 14th European Colloquium on Theoretical and Quantitative Geography, Setembro, Portugal, 28-30 September 2005.

28. Encarnação, S.; Gaudiano, M.; Santos, F.C.; Tenedório, J.A.; Pacheco, J.M. Fractal cartography of urban areas. Sci. Rep. 2012, 2, 527. [CrossRef] [PubMed]

29. Vale, M.J.; Reis, R.; Meneses, B.M. A caraterização do uso e ocupação do solo de Portugal Continental. In Uso e Ocupação do Solo em Portugal Continental: Avaliação e Cenários Futuros, Projeto LANDYN; DGT, Ed.; Direção-Geral do Território: Lisboa, Portugal, 2014; pp. 1-5.

30. Meneses, B.M. Analysis of Land Use and Land Cover Changes in the Valley of the Varosa (Portugal) by Landsat-TM Images and its Influence on Soil Conservation. GeoFocus 2013, 13, 270-290. (In Portuguese)

31. ESRI ArcGIS Help Library. Available online: http://resources.arcgis.com/en/help/main/10.1/index.html\# / / 001200000030000000 (accessed on 31 October 2017).

32. Roy, D.P.; Wulder, M.A.; Loveland, T.R.; Woodcock, C.E.; Allen, R.G.; Anderson, M.C.; Helder, D.; Irons, J.R.; Johnson, D.M.; Kennedy, R.; et al. Landsat-8: Science and product vision for terrestrial global change research. Remote Sens. Environ. 2014, 145, 154-172. [CrossRef]

33. Mandanici, E.; Bitelli, G. Preliminary comparison of sentinel-2 and landsat 8 imagery for a combined use. Remote Sens. 2016, 8, 1014. [CrossRef]

34. Ma, L.; Cheng, L.; Li, M.; Liu, Y.; Ma, X. Training set size, scale, and features in Geographic Object-Based Image Analysis of very high resolution unmanned aerial vehicle imagery. ISPRS J. Photogramm. Remote Sens. 2015, 102, 14-27. [CrossRef]

35. Senthilnath, J.; Kandukuri, M.; Dokania, A.; Ramesh, K.N. Application of UAV imaging platform for vegetation analysis based on spectral-spatial methods. Comput. Electron. Agric. 2017, 140, 8-24. [CrossRef]

36. Fröhlich, B.; Bach, E.; Walde, I.; Hese, S.; Schmullius, C.; Denzler, J. Land Cover Classification of Satellite Images Using Contextual Information. ISPRS Ann. Photogramm. Remote Sens. Spat. Inf. Sci. 2013, 3, w1. [CrossRef]

37. Carleer, A.P.; Debeir, O.; Wolff, E. Assessment of very high spatial resolution satellite image segmentations. Photogramm. Eng. Remote Sens. 2005, 71, 1285-1294. [CrossRef]

38. Bai, X.; Sharma, R.C.; Tateishi, R.; Kondoh, A.; Wuliangha, B.; Tana, G. A Detailed and High-Resolution Land Use and Land Cover Change Analysis over the Past 16 Years in the Horqin Sandy Land, Inner Mongolia. Math. Probl. Eng. 2017, 2017. [CrossRef]

39. Meneses, B.M.; Reis, E.; Vale, M.J.; Reis, R. Modeling land use and land cover changes in Portugal: A multi-scale and multi-temporal approach. Finisterra 2018. [CrossRef]

40. Veregin, H. Data Quality Measurement and Assessment; National Centre for Geographic Information and Analysis, University of California at Santa Barbara: Santa Barbara, CA, USA, 1998.

41. Veregin, H.; Lanter, D.P. Data-quality enhancement Techniques in layer-based Geographic Information Systems. Comput. Environ. Urban Syst. 1995, 19, 23-36. [CrossRef]

42. Goodchild, M.F.; Li, L. Assuring the quality of volunteered geographic information. Spat. Stat. 2012, 1, 110-120. [CrossRef]

43. Comber, A.; See, L.; Fritz, S.; Van Der Velde, M.; Perger, C.; Foody, G. Using control data to determine the reliability of volunteered geographic information about land cover. Int. J. Appl. Earth Obs. Geoinf. 2013, 23, 37-48. [CrossRef]

44. Droj, G.; Suba, S.; Buba, A. Modern techniques for evaluation of spatial data quality. RevCAD J. Geod. Cadastre 2010, 265-272.

45. Huisman, O.; de By, R.A. Principles of Geographic Information Systems; Huisman, O., de By, R.A., Eds.; International Institute for Geo-Information Science and Earth Observation: Enschede, The Netherlands, 2009.

46. Jaakkola, O. Quality of multiscale land cover data. In Geographical Information '97, Proceedings of the Third Joint European Conference E Exhibition on Geographical Information, Vienna, Austria, 16-18 April 1997; Hodgson, S., Rumor, M., Harts, J.J., Eds.; IOS Press: Vienna, Austria, 1997; pp. 335-344.

47. Raposo, P.; Brewer, C.A.; Sparks, K. An impressionistic cartographic solution for base map land cover with coarse pixel data. Cartogr. Perspect. 2016, 83, 5-21. [CrossRef]

48. Raposo, P.; Samsonov, T. Towards general theory of raster data generalization. In Proceedings of the 17th ICA Workshop on Generalisation and Multiple Representation, Vienna, Austria, 23 September 2014; p. 10. 
49. Shea, K.S.; McMaster, R.B. Cartographic generalization in a digital environment: When and how to generalize. In Proceedings of the AutoCarto, Baltimore, ML, USA, 2-7 April 1989; Volume 9, pp. 56-67.

50. Couclelis, H. People manipulate objects (but cultivate fields): Beyond the Raster-Vector Debate in GIS. Theor. Methods Spat. Reason. Geogr. Spat. 1992, 639, 65-77.

51. Longley, P.A.; Goodchild, M.F.; Maguire, D.J.; Rhind, D.W. Geographical Information Systems and Science, 2nd ed.; John Wiley \& Sons, Ltd.: Chichester, UK, 2005.

52. Ladra, S.; Paramá, J.R.; Silva-Coira, F. Scalable and Queryable Compressed Storage Structure for Raster Data. Inf. Syst. 2017, 72, 179-204. [CrossRef]

53. Liu, Y.; Goodchild, M.F.; Guo, Q.; Tian, Y.; Wu, L. Towards a General Field model and its order in GIS. Int. J. Geogr. Inf. Sci. 2008, 22, 623-643. [CrossRef]

54. Orongo, N.D. GIS Based: Cartographic Generalization in Multi-scale Environment: Lamu County; University of Nairobi: Nairobi, Kenya, 2011.

55. University of British Columbia (Department of Geography) Scale, Accuracy, and Resolution in a GIS. Available online: http:/ /ibis.geog.ubc.ca/ brian/Course.Notes/gisscale.html (accessed on 22 October 2017).

56. Veregin, H.; Mcmaster, R. Data Quality Implications of Raster Generalization. In Proceedings of the AutoCarto-13, Seattle, WA, USA, 7-10 April 1997; pp. 267-276.

57. Congalton, R.G. A review of assessing the accuracy of classifications of remotely sensed data. Remote Sens. Environ. 1991, 37, 35-46. [CrossRef]

58. Rodriguez-Galiano, V.; Chica-Olmo, M. Land cover change analysis of a Mediterranean area in Spain using different sources of data: Multi-seasonal Landsat images, land surface temperature, digital terrain models and texture. Appl. Geogr. 2012, 35, 208-218. [CrossRef]

59. Regos, A.; Ninyerola, M.; Moré, G.; Pons, X. Linking land cover dynamics with driving forces in mountain landscape of the Northwestern Iberian Peninsula. Int. J. Appl. Earth Obs. Geoinf. 2015, 38, 1-14. [CrossRef]

60. Jung, M.; Henkel, K.; Herold, M.; Churkina, G. Exploiting synergies of global land cover products for carbon cycle modeling. Remote Sens. Environ. 2006, 101, 534-553. [CrossRef]

61. Pôças, I.; Cunha, M.; Marcal, A.R.S.; Pereira, L.S. An evaluation of changes in a mountainous rural landscape of Northeast Portugal using remotely sensed data. Landsc. Urban Plan. 2011, 101, 253-261. [CrossRef]

62. Aitkenhead, M.J.; Aalders, I.H. Automating land cover mapping of Scotland using expert system and knowledge integration methods. Remote Sens. Environ. 2011, 115, 1285-1295. [CrossRef]

63. Theobald, D.M. Reducing Linear and Perimeter Measurement Errors in Raster-based Data. Cartogr. Geogr. Inf. Sci. 2000, 406, 37-41. [CrossRef]

64. Wade, T.G.; Wickham, J.D.; Nash, M.S.; Neale, A.C.; Riitters, K.H.; Jones, K.B. A Comparison of Vector and Raster GIS Methods for Calculating Landscape Metrics Used in Environmental Assessments. Photogramm. Eng. Remote Sens. 2003, 69, 1399-1405. [CrossRef]

65. Sleeter, B.M.; Sohl, T.L.; Bouchard, M.A.; Reker, R.R.; Soulard, C.E.; Acevedo, W.; Griffith, G.E.; Sleeter, R.R.; Auch, R.F.; Sayler, K.L.; et al. Scenarios of land use and land cover change in the conterminous United States: Utilizing the special report on emission scenarios at ecoregional scales. Glob. Environ. Chang. 2012, 22, 896-914. [CrossRef]

66. Giri, C.; Pengra, B.; Long, J.; Loveland, T.R. Next generation of global land cover characterization, mapping, and monitoring. Int. J. Appl. Earth Obs. Geoinf. 2013, 25, 30-37. [CrossRef]

67. Ahearn, D.S.; Sheibley, R.W.; Dahlgren, R.A.; Anderson, M.; Johnson, J.; Tate, K.W. Land use and land cover influence on water quality in the last free-flowing river draining the western Sierra Nevada, California. J. Hydrol. 2005, 313, 234-247. [CrossRef]

68. Teixeira, Z.; Teixeira, H.; Marques, J.C. Systematic processes of land use/land cover change to identify relevant driving forces: Implications on water quality. Sci. Total Environ. 2014, 471, 1320-1335. [CrossRef] [PubMed]

69. Autoridade Florestal Nacional. Nemátodo da Madeira do Pinheiro-Atividades Realizadas no Âmbito do Seu Controlo; Autoridade Florestal Nacional: Lisboa, Portugal, 2012.

70. EEA. CLC2006 Technical Guidelines; European Environment Agency: Copenhagen, Denmark, 2007; Volume 2010.

71. EEA. CORINE Land Cover; European Environment Agency: Copenhagen, Denmark, 1995. 
72. DGT. Land Use and Land Cover Evolutions in Continental Portugal, Work to Support Reporting of Emissions and Carbon Sequestration in the Sector Use and Land Use Changes; Kyoto Protocol and United Nations Framework Convention on Climate Changes: Lisbon, Portugal, 2014.

73. Meneses, B.M.; Reis, R.; Vale, M.J.; Saraiva, R. Land use and land cover changes in Zêzere watershed (Portugal)—Water quality implications. Sci. Total Environ. 2015, 527, 439-447. [CrossRef] [PubMed]

74. Shi, P.; Chen, J.; Pan, Y. Land use change mechanism in Shenzhen City. Acta Geogr. Sin. 2000, 67, 151-160.

75. Zhang, X.; Zhang, L.; He, C.; Li, J.; Jiang, Y.; Ma, L. Quantifying the impacts of land use/land cover change on groundwater depletion in Northwestern China-A case study of the Dunhuang oasis. Agric. Water Manag. 2014, 146, 270-279. [CrossRef]

76. Hidore, J.J. Landform characteristics affecting watershed yields on the Mississippi-Missouri interfluve. Proc. Oklahoma Acad. Sci. 1964, 45, 201-203.

77. Bolstad, P. Data Models. In GIS Fundamentals: A First Text on Geographic Information Systems; Bolstad, P., Ed.; Eider Press: White Bear Lake, MN, USA, 2012; pp. 23-56.

78. Davis, B.E. GIS: A Visual Approach, 2nd ed.; Davis, B.E., Ed.; Onword Press Thomson Learning: Albany, NY, USA, 2001.

79. Wehde, M. Grid cell size in relation to errors in maps and inventories produced by computerized map processing. Photogramm. Eng. Remote Sens. 1982, 48, 1289-1298.

80. Congalton, R.G. Exploring and evaluating the consequences of vector-to-raster and raster-to-vector conversion. Photogramm. Eng. Remote Sens. 1997, 63, 425-434.

81. Carver, S.J.; Brunsdon, C.F. Vector to raster conversion error and feature complexity: An empirical study using simulated data. Int. J. Geogr. Inf. Syst. 1994, 8, 261-270. [CrossRef]

82. Yang, J.; Li, Y.; Xi, J.; Li, C.; Xie, F. Study on semantic contrast evaluation based on vector and raster data patch generalization. Abstr. Appl. Anal. 2014, 2014. [CrossRef]

83. Liao, S.; Bai, Z.; Bai, Y. Errors prediction for vector-to-raster conversion based on map load and cell size. Chin. Geogr. Sci. 2012, 22, 695-704. [CrossRef]

84. Clarke, K.C. A comparative analysis of polygon to raster interpolation methods. Photogramm. Eng. Remote Sens. 1985, 51, 575-582.

85. Veregin, H. A review of error models for vector to raster conversion. Oper. Geogr. 1989, 7, 11-15.

86. Cámara, M.; López, F. Mathematical Morphology Applied to Raster Generalization of Urban City Block Maps. Cartogr. Int. J. Geogr. Inf. Geovis. 2000, 37, 33-48. [CrossRef]

87. Meneses, B.M.; Reis, E.; Vale, M.J.; Reis, R. Modeling the Probability of Surface Artificialization in Zêzere Watershed (Portugal) Using Environmental Data. Water 2016, 8, 289. [CrossRef]

88. Stoter, J.; Post, M.; van Altena, V.; Nijhuis, R.; Bruns, B. Fully automated generalization of a 1:50k map from 1:10k data. Cartogr. Geogr. Inf. Sci. 2014, 41, 1-13. 